Article

\title{
Early Silurian (Aeronian) East Point Coral Patch Reefs of Anticosti Island, Eastern Canada: First Reef Recovery from the Ordovician/Silurian Mass Extinction in Eastern Laurentia
}

\author{
Paul Copper $^{1, *}$ and Jisuo Jin ${ }^{2}$ \\ 1 Loupicoubas, 46220 Prayssac, France \\ 2 Department of Earth Sciences, Western University, London N6A 5B7, Canada; E-Mail: jjin@uwo.ca \\ * Author to whom correspondence should be addressed; E-Mail: pcopper@laurentian.ca; \\ Tel.: +011-33-565-22-65-81.
}

Received: 5 April 2012; in revised form: 11 May 2012 / Accepted: 15 May 2012 /

Published: 24 May 2012

\begin{abstract}
An extensive late Aeronian patch reef swarm outcrops for $60-70 \mathrm{~km}$ on Anticosti Island, eastern Canada, located in the inner to mid-shelf area of a prominent tropical carbonate platform of southeastern Laurentia, at $20^{\circ}-25^{\circ} \mathrm{S}$ paleolatitude of the southern typhoon belt. This complex, described here for the first time, includes more than 100 patch reefs, up to $60-80 \mathrm{~m}$ in diameter and $10 \mathrm{~m}$ high. Reefs are exposed three-dimensionally on present-day tidal flats, as well as inland along roads and rivers. Down the gentle $1^{\circ}-2^{\circ}$ paleoslope, the reefs grade into coral-sponge biostromes, and westerly they grade into inter-reef or deeper 'crinoidal meadow' facies. The reef builders were dominantly tabulate and rugose corals, with lesser stromatoporoids. Other components include crinoids, brachiopods, green algae (especially paleoporellids), and encrusting cyanobacteria: reefs display some of the earliest known symbiotic intergrowths of corals and stromatoporoids. Reefs were variably built on a base of crinoidal grainstones, meadows of baffling tabulate corals, brachiopod shells, or chlorophytes. These reefs mark an early phase of reef recovery after a prominent reef gap of 5-6 million years following the Ordovician/Silurian mass extinction events. The reefs feature a maximal diversity of calcifying cyanobacteria, corals and stromatoporoids, but low diversity of brachiopods, nautiloids and crinoids. Following the North American Stratigraphic Code, we define herein the Menier Formation, encompassing the lower two members of the existing Jupiter Formation.
\end{abstract}


Keywords: coral reefs; post-extinction recovery; early Silurian; Anticosti Island

\section{Introduction}

The roughly three million year long, end-Ordovician (late Katian-Hirnantian) mass extinction was marked by at least three major glacial episodes on the North Gondwana Platform, extending from Morocco to Oman, and including Spain and Portugal [1]. Adjacent cold climate areas in the southern hemisphere were also glaciated [2,3], or had extensive marine ice shelf coverage [4]. Latest Ordovician (late Katian and Hirnantian) glaciations were accompanied by sealevel lowstands that exposed much of the paleocontinent of Laurentia, resulting in extensive hiatuses in the fossil record of reefs. However, in areas on the continental margins of Laurentia, with inner to mid-shelf facies, reefs developed within the mid to late Hirnantian [5,6] leaving a record of the coral and stromatoporoid faunas of the end Ordovician [7]. This Hirnantian reef fauna essentially vanished with only a few hold-overs, such as the phaceloid reef-builder Palaeophyllum. Anticosti Island (Figure 1), with a virtually uninterrupted $800 \mathrm{~m}$ thick section across the Ordovician-Silurian boundary, is an ideal location to study extinction and recovery impacts in the reef setting.

The earliest Silurian (Rhuddanian) reef record is very sparse worldwide [8-10]. One of the few places where earliest Rhuddanian coral reefs are present is at the eastern end of Manitoulin Island, Canada, in the Michigan Basin [11]. Bergström et al. [12] have suggested that the Manitoulin reefs were late Hirnantian in age. Nevertheless, the Manitoulin reefs lack the distinctive aulaceratid-clathrodictyid sponge and tetradiid-rugose coral faunas typical of the Hirnantian reefs of both Anticosti and Estonia. The Manitoulin reefs also overlie the occurrence of the brachiopod genus Zygospiraella, diagnostic of the early Rhuddanian of Anticosti Island and the Baltic region. Middle- to late Rhuddanian reefs are known from the Baltic region, where they are assigned to the Tammiku Member (Tamsalu Formation) and the Hilliste Formation $[13,14]$. These Rhuddanian reefs, of which there were three types in Estonia, are not presently described in great detail. The tabulate corals (initially auloporids with algae in the middle-late Rhuddanian Tammiku Member, then primarily favositids and halysitids in the Hilliste Formation of late Rhuddanian to early Aeronian age) formed a major role [15]. Colonial rugose corals were also reef dwellers (e.g., Paliphyllum, Palaeophyllum, Cyathophylloides, Petrozium, Entelophyllum), and have been described by Kaljo [16]. The coral fauna characteristic of the Rhuddanian Becscie Formation of Anticosti is similar to that of the Manitoulin reefs and the Rhuddanian reefs of Estonia. The whole Rhuddanian sequence of Estonia is no more than $64 \mathrm{~m}$ thick: on Anticosti the Rhuddanian is about $200 \mathrm{~m}$ thick.

At present, there is a lack of detailed knowledge about most of the earliest Silurian (Rhuddanian) reefs in terms of their faunal composition (such as what phyla and genera dominated), and structure (how these constructed or modified the reefs). On Anticosti, the Rhuddanian upper Becscie Formation (Chabot Member) and succeeding Merrimack Formation developed local clusters or concentrations of the phaceloid rugosans Nanophyllum, Palaeophyllum and Donacophyllum, but these did not build reefs. Even the early through mid- Aeronian Gun River and lower Menier formations show no reef growth. The late Aeronian East Point reefs are younger than those of Estonia, have a different fauna, and mark the first Silurian reef development on the Anticosti Platform. We provide information on the 
'first arrivals' of taxa, in terms of reef builders for the Rhuddanian and Aeronian. For example, when or where precisely did the Silurian reef-builders (e.g., alveolitids, coenitids, multisolenids and pachyporids) originate, that subsequently dominated reef settings in the Middle Silurian (Wenlock) through Devonian? Did some of these arise in the transitional latest Ordovician (Hirnantian) stage, or were they a newly evolved component of the later recovery fauna? What is the fossil record of bio-eroders?

Figure 1. Geologic map of the central and eastern parts of Anticosti Island, Gulf of St Lawrence showing the outcrop pattern of the East Point Member of the Menier Formation, and known reef, biostrome and crinoidal meadow distribution. Note that the paleoslope dipped to deeper waters in a southerly direction, with reefs mostly in the northern, shallower end of the carbonate platform. No nearshore intertidal facies are known to the north.
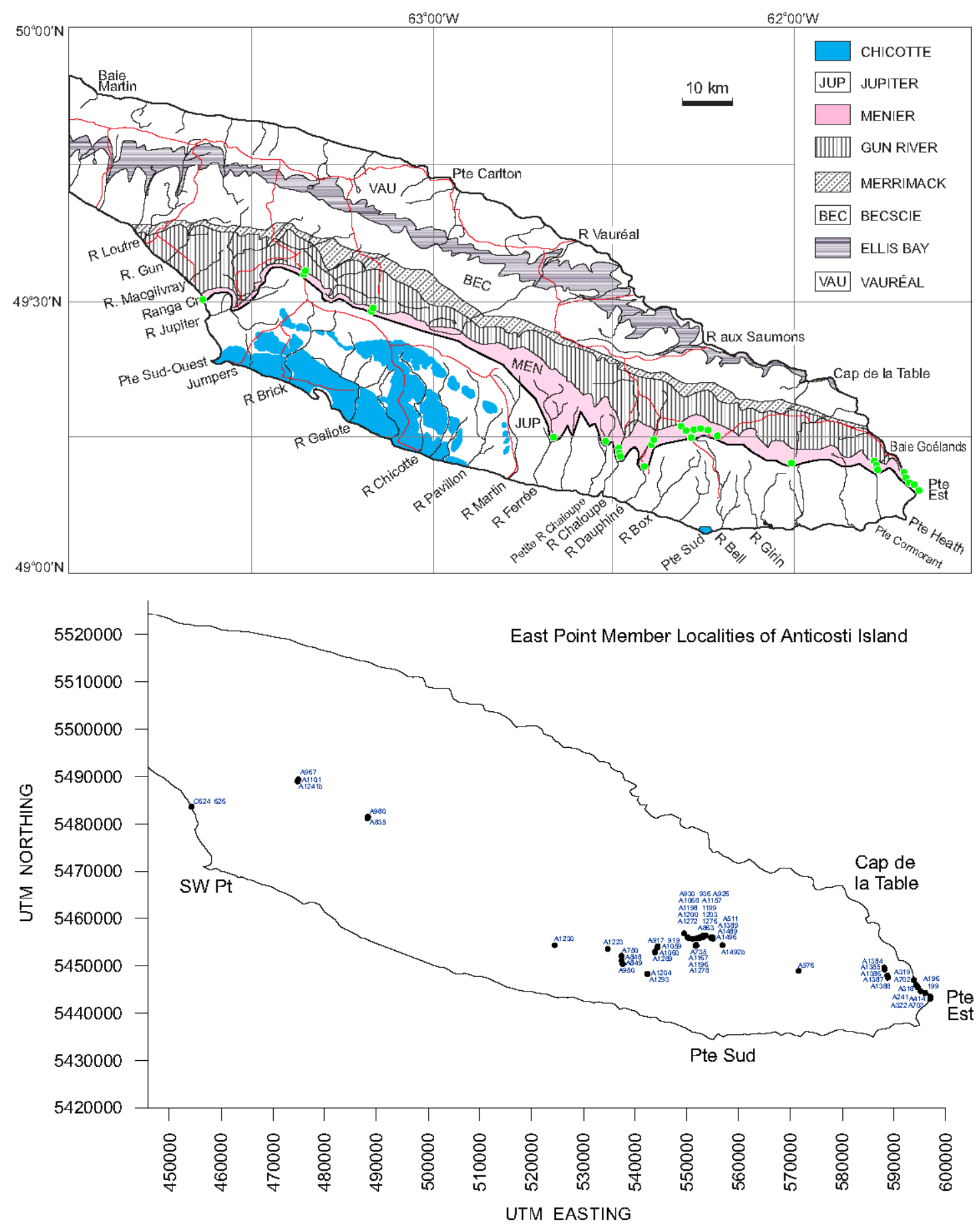
This paper is a contribution to the theme of recovery of reef taxa and reefs after the end Ordovician mass extinction events, as seen in the Anticosti Basin of eastern Laurentia. It records the transitional coral and stromatoporoid fauna, and associated reef inhabitants that marked reefs of Aeronian (middle Llandovery) age on the margins of the Laurentia paleoplate. These earliest Silurian reefs were thus built at a time of global re-warming and rising sealevels, following a Late Ordovician ice age that lasted about the same length of time as the Pleistocene glacial episodes, i.e., 3 million years. Coral and stromatoporoid biodiversity increases on Anticosti Island began already in middle Rhuddanian time, with rising sealevel and warming, as seen in the faunas of the Becscie and Merrimack formations [17,18]. Nevertheless, no reefs developed in the Anticosti section until deposition of the carbonates the East Point Member, in the Menier Formation, some $300 \mathrm{~m}$ above the base of the Early Silurian section. Compared with Estonia in the Baltic Basin, on the opposite side of the ancient Iapetus ocean [14,16,19], the Anticosti Silurian carbonate section is three to four times thicker, and fills in, for example, the faunal gaps of the more condensed, and hiatus-prone, Estonian sequence [7].

All samples mentioned or illustrated in this study are in the repository of the Geological Survey of Canada, Ottawa, with catalogued samples denoted by the prefix GSC, and locality numbers preceded by the letter "A".

\section{The Anticosti Section}

In 1856 James Richardson departed for an epic boat journey around Anticosti Island in the Gulf of St Lawrence, charged with mapping and measuring stratigraphic sections, and collecting fossils to establish their age [20]. In the process, he was the first to discover, and briefly describe, the fossil reefs at East Point (Figure 1), which he assigned to the top of his Division D. He described these strata as " $25 \mathrm{ft}, \ldots$ charged with a multitude of corals...the bed assumed a hummocky character... some patches of the corals rising from one to five feet high". Schuchert and Twenhofel [21], following field work from a boat in 1906, re-examined the East Point outcrops along the north coast, and were the first to note that this unit was "a coral reef... essentially of corals", but they mistakenly correlated the strata to near the top of their freshly dedicated Gun River Formation, named from the south coast some $120 \mathrm{~km}$ to the west. Later, Twenhofel [22] placed the East Point 'extensive coral reef' at the base of the Jupiter Formation and confirmed that stratigraphic position for his "coral reef limestone of variable thickness" [23]. Schuchert and Twenhofel were never able to visit the 3-4 km long overhanging Goéland cliffs west of East Point, as these are located along a dangerous storm-swept part of the coast that is poorly accessible except by zodiac or helicopter, even today. Nor did they land at what is today called the "Baie aux Goélands": if so, they would probably have understood that the base of their Jupiter Formation lay well below the East Point reefs.

In 1972 Bolton went to the east end of the island by float plane and examined the East Point reefs and the recessive shales above them, allocating the reefs to the base of the Jupiter Formation (as had Twenhofel in 1921 and 1928 before him). Neither did Bolton visit the Goéland cliffs section to the west. On the other hand, using helicopter support, Petryk [24,25] placed the East Point reefs at the top of the Gun River Formation, and used that to draw the boundary between the Gun River and Jupiter formations at the north side of the island. Thus the East Point reefs have had a mixed correlation history in the past. Copper first visited the East Point section by boat in 1978 (and subsequently), collecting samples from the reefs. Copper and Long [26], after spending several field seasons by boat 
circumnavigating the island, established the East Point reef unit as an independent member of the Jupiter Formation, which was reconfirmed in Copper and Brunton [8]. The East Point Member, with its base some $55 \mathrm{~m}$ above the base of the original Jupiter Formation, overlies the easily identifiable recessive shales with rich in situ pentamerid brachiopod faunas of the Goéland Member below it [27,28]. Since 1984, we have been able to map the reefs far inland by road, and their equivalent crinoidal grainstones some $160 \mathrm{~km}$ to the west near Cape Macgilvray, including outcrops along the coast and rivers [5] (Figure 1). Faunal correlations of the reefal stromatoporoids, e.g., the possibly endemic genus Tarphystroma [7] and rugose corals, with the presence of a Siberian genus, Palaearaea [29], confirm a late Aeronian age for the East Point Member. Apart from some preliminary data on the distribution of the East Point reefs as part of field guides [30,31], this is the first time the East Point reef-builders and their associated facies are described in some detail.

We herein include the Aeronian East Point reefal unit (Figure 2), and the Goéland Member below, in a new Menier Formation. In accordance with North American Stratigraphic Code, the definition of the Menier Formation is outlined as follows:

(1) The intent to designate a formal unit. The Menier Formation is proposed herein as a formal stratigraphic unit.

(2) Category and rank of unit. Menier Formation (new), consists of the two previously established Goéland and East Point members.

(3) Selection and derivation of the name. The new formation is named after the Menier family from Chateau Chenonceau, France, the owners of Anticosti Island after Louis Jolliet.

(4) Stratotype of the two members. See Copper and Long [26].

(5) Description of unit. See formal descriptions of the Goéland and East Point members by Copper and Long [26].

(6) Boundaries. The lower boundary of the Menier Formation is the base of the Goéland Member, and the upper boundary the top of the East Point Member, as defined in Copper and Long [26].

(7) Historical background. See Copper and Long [26].

(8) Dimensions of the unit. The Menier Formation has a total thickness of $65 \mathrm{~m}$, and extends from the eastern end to the southwestern coast of Anticosti Island as a continuous belt (Figure 1).

(9) Age and correlations. The first appearance datum (FAD) of Kulumbella and Pentamerus in the uppermost Macgilvray Member of the Gun River Formation, which directly underlies the Menier Formation, indicates a mid-Aeronian age. Corals and brachiopods within the new formation carry elements readily differentiated from those of the overlying Jupiter and Chicotte formations. The Richardson and lower Cybèle members of the Jupiter Formation above carry a Stimulograptus sedgwicki fauna, denoting a latest Aeronian age. The base of the East Point Member in the Box River region contains common graptolites alongside abundant Stegerhynchus, although the graptolites remain to be identified. The faunal data, therefore, suggest a mid- to late Aeronian age for the Menier Formation. 
Figure 2. Stratigraphic column of the $400 \mathrm{~m}$ thick Lower Silurian strata on Anticosti Island, beginning at the top of the Hirnantian Ellis Bay Formation, and terminated by the Telychian Chicotte Formation. The Menier Formation comprises the two lower members of the original Jupiter Formation, i.e., the Aeronian deeper shales and limestones of the Goéland Member and reefal-crinoidal carbonates of the East Point Member. Stromatoporoid diversity data from Nestor et al. [7], and coral data from McLean and Copper [29].

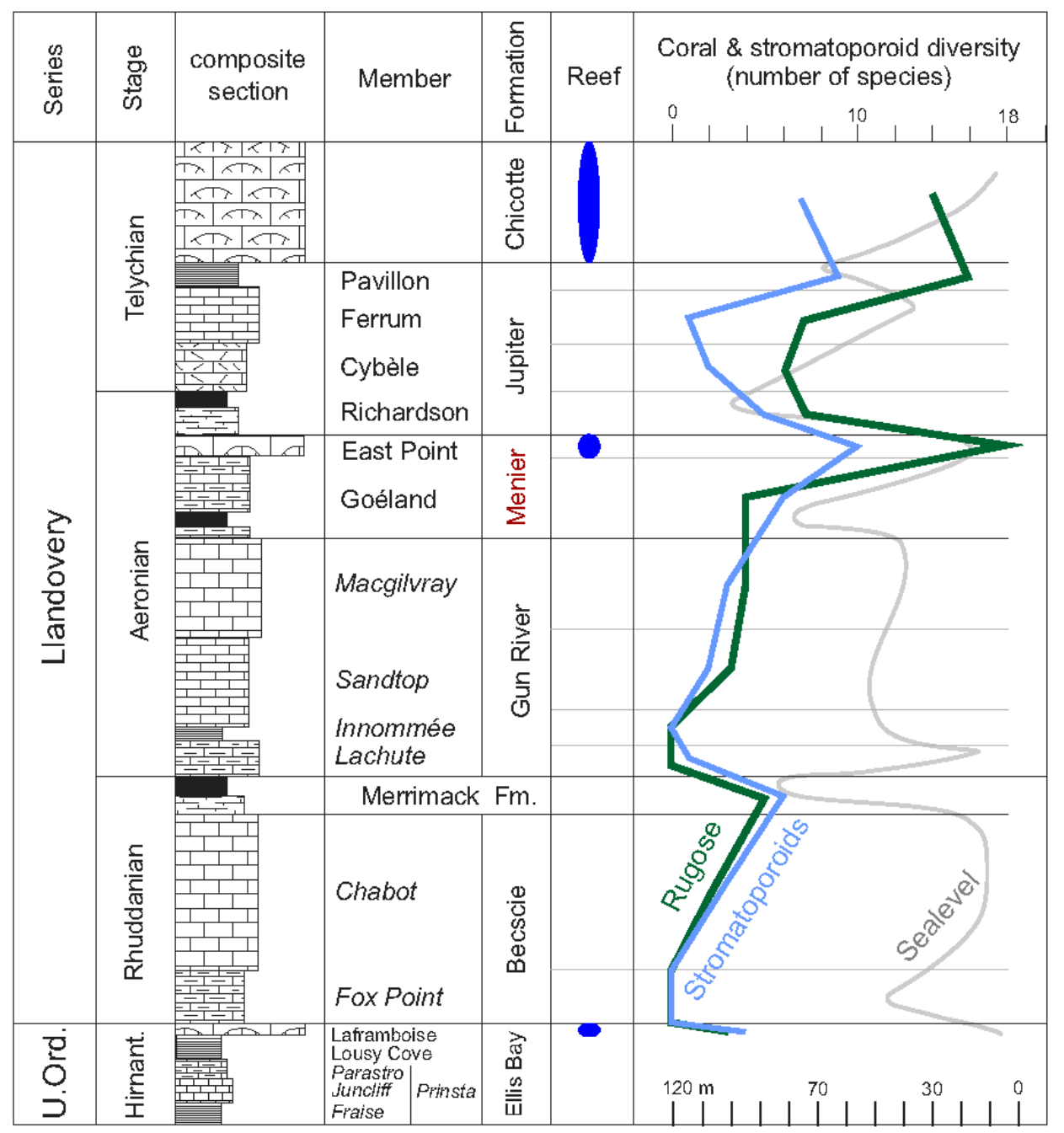

\section{Distribution and Geometry of the East Point Reefs}

The Aeronian reef belt stretches from East Point itself, the most easterly protrusion of Anticosti Island, where it outcrops in the bluffs and along the tidal flats, to as far west as the Box River, some $70 \mathrm{~km}$ away (see Figure 1). The crinoidal meadow facies of the East Point Member thins to $<1 \mathrm{~m}$ in coastal outcrops west of the Jupiter River. Reefs are thickest and most prominently and three-dimensionally exposed along the cliffs and tidal flats at, and to ca. $6 \mathrm{~km}$ west of East Point (Figures 3-5). They taper out below overlying shales of the Richardson Member up section to the south around East Point (Figure 3e). The reefs at East Point are 5-10 m thick overall, but may be thicker locally. Diameters range from about 10 to $60 \mathrm{~m}$ in this area, but seem to be greater inland along the main road, $\mathrm{ca} .40 \mathrm{~km}$ to the west and north. Some of the reefs are stacked multiple-levels in the bluffs and cliffs (Figures $4 \mathrm{c}$ and 5), and others are displaced laterally above underlying reef levels. This suggests 
multiple reef-building events, and discontinuous growth, or amalgamation of adjacent and overlying reefs, over a wide area. In the tidal flat sections at East Point, the reef bases are not exposed, but they lie over a $c a .1 \mathrm{~m}$ thick grainstone bed (Figure 4c). They are only rarely and partly accessible in the lower bluff and cliff faces, and via erosional collapse of the cliff face in the coastal cliffs to the west (Figures $3 \mathrm{f}$ and $5 b$ ).

Figure 3. Helicopter views at East Point. (a) tidal flat and bluffs some $500 \mathrm{~m} \mathrm{NW}$ of East Point, displaying ca. 15 reefs on the tidal flats; (b) view of about ten reefs in the bluffs and on the tidal flats, and exposing most of the member; (c) western tidal flat outcrops of the reefs, close to where the base of the member occurs: an isolated large reef at the right side is 50-60 m across; (d) tidal flat outcrop at East Point, marked by several large, partially wave-eroded reef cores and flanks (Darrel Long for scale, facing a reef core to the right); (e) East Point itself (bluff jutting out to the right), with last of the easterly reef outcrops, and the overlying recessive shaly Richardson Member of the bluffs, in turn covered by the resistant weathering Cybèle Member of the Jupiter Formation; (f) most westerly accessible reef outcrop, showing almost the full thickness of the East Point Member (top of cliff with about $3 \mathrm{~m}$ thick glacial deposits) and 4-7 m of the underlying Goéland Member of the Menier Formation (A241, location of shipwreck).
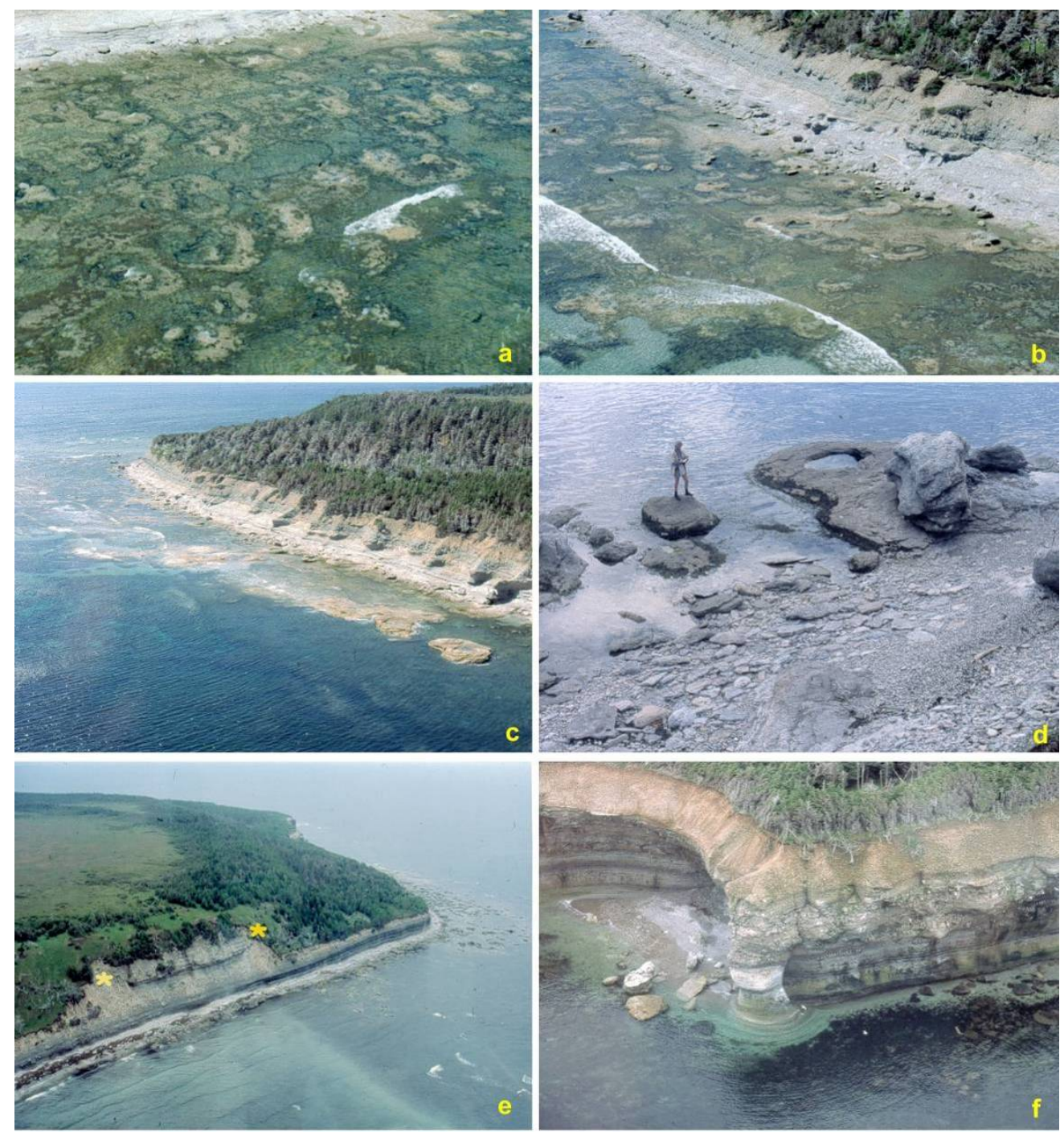
Figure 4. Helicopter views East Point reef outcrops. (a) panoramic shot of the reef outcrops on the tidal flats, looking WNW towards Goéland cliffs: in the distance the reefs are shown within the cliff exposures; (b) reefs on the tidal flats in the area close to East Point, shown at partial low tide; (c) bluff and lower level exposures of the East Point reefs ca. $1 \mathrm{~km} \mathrm{~W}$ of East Point: note that the reefs were developed discontinuously at several levels through the 12-13 m thickness of the member; (d) reefs on the tidal flats at the western end of the reefal outcrops, some subtidally submerged and some close to low tide level; (e) Over 20 reefs exposed at low tide, with some displayed within the adjacent bluffs; (f) about eight reefs exposed on the tidal flats, with further reefs in the middle and upper East Point Member.
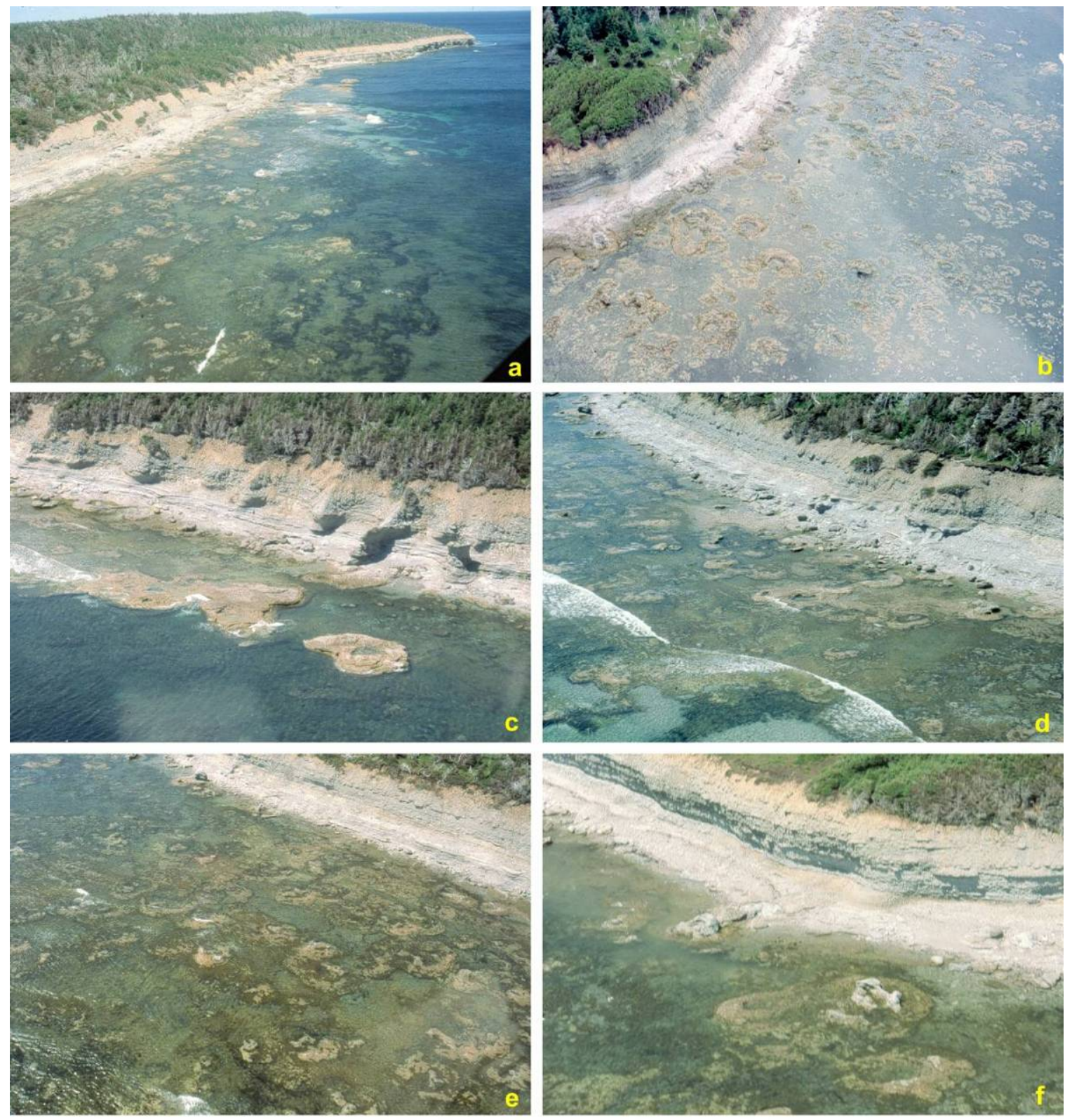
Figure 5. Outcrop views at East Point. (a) western panoramic view of the reef swarm on the tidal flats, taken from the bluff top, direction of Goéland Cliffs in the distance; (b) East Point reef swarm at low tide direction eastwards near East Point itself; (c) panoramic view of a single patch reef ( $c a .30 \mathrm{~m}$ in diameter) at low tide (human for scale); (d) panoramic view of several irregular to circular patch reef tops at intermediate tide, with reef cores partly eroded on this modern wave-cut platform.
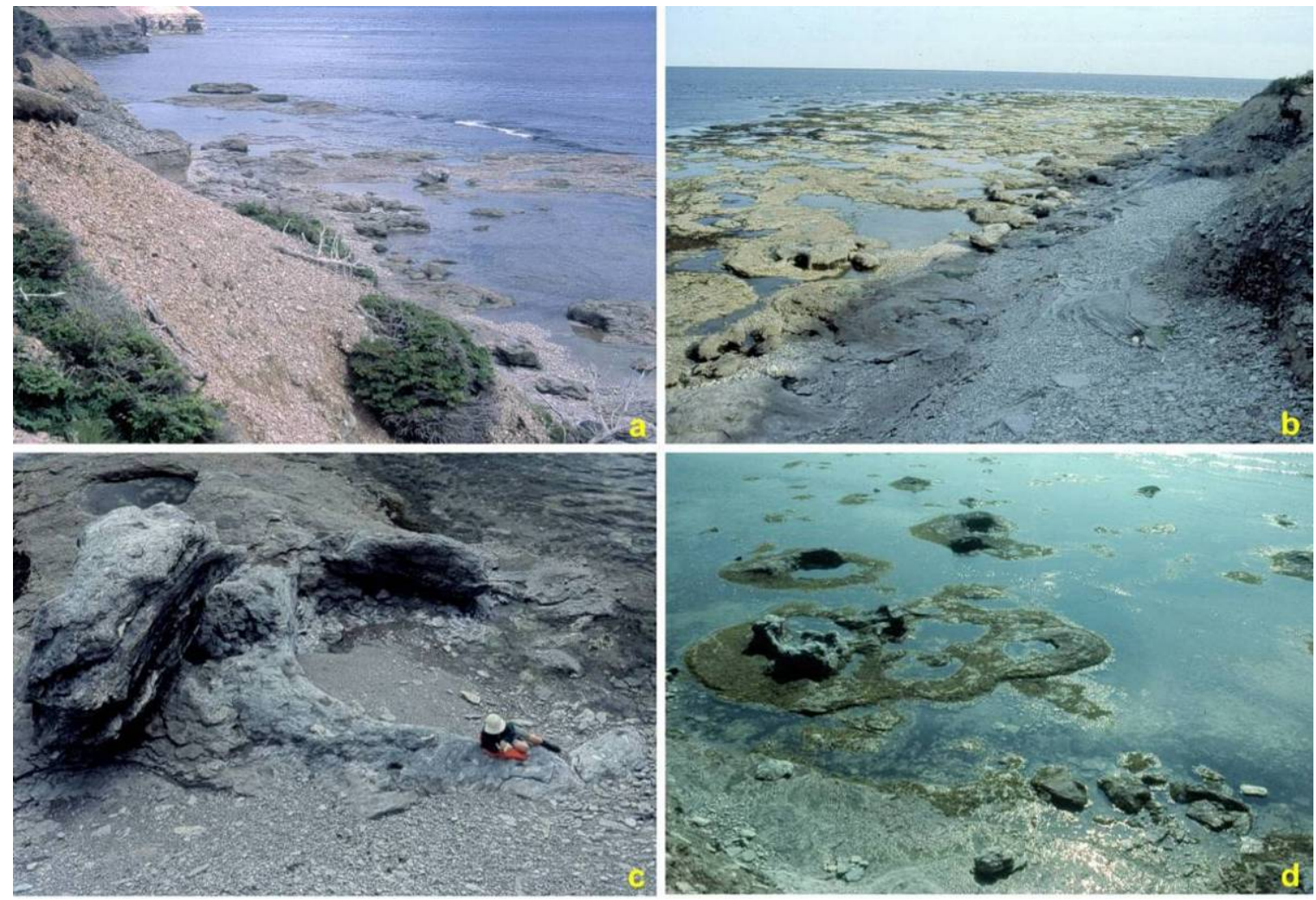

The foundations of the reefs are better exposed in two road-cuts along the main road, showing also the reef bases, cores, tops and flanks beds, $c a .2 \mathrm{~km}$ to the east of the Box road junction (e.g., outcrops A863, A1198, A1199, with about $200 \mathrm{~m}$ separating the two reefs). In the Chaloupe River to Ferrée River areas, reefs give way down the carbonate ramp to both crinoidal or biostromal facies of less than $3 \mathrm{~m}$ thickness. The biostromal facies is well displayed along the east bank of the Dauphiné River (A1204, 12E/1, 42350:48280) and on the Petite Rivière de la Chaloupe (A1223, 12E/2, 34700:53580). West of the Ferrée River, towards the mouth of the Jupiter River and Triplesia Creek, and inland along the Firetower road, only the crinoid meadow facies is evident. The East Point Member there shrinks to $<1 \mathrm{~m}$ in thickness; locally it may even be so thin and poorly exposed as to become difficult to find in road outcrop.

The three-dimensional outcrops of patch reefs along the East Point tidal flats point to two aspects: (1) most of the reefs have an irregular to circular outline, with diameters ranging from about $3 \mathrm{~m}$ to 50-60 m, as seen from above by helicopter and from the bluff tops (Figures 3 and 4), and (2) they are relatively closely spaced, 10-50 m apart (Figures 3-5). Some reefs that started separately appear to have amalgamated into a larger cluster (e.g., Figure 4c). Individual patch reefs appear to lack a definable windward or leeward side, in terms of a fore-reef rubble zone, or less developed leeward side. The patch reef complex as a whole, and individual reefs, show no orientation or elongation into a 
possible current or windward wave direction and dispersal appears to be random, and not in any way aligned. This suggests that for the East Point coastal area itself, there was no tidal influence, such as tidal channels or windward wave direction, which affected reef shape, orientation or density (as seen in the much younger Telychian reefs of the Chicotte Formation). This suggests that at the east end of the island, waters were probably slightly deeper and less exposed to storm effects, possibly growing at depths of $10 \mathrm{~m}$ or more. Comparable patch reef patterns today might be those of the inner Swain Reefs of the Great Barrier Reef shelf [32]. Alternatively, the East Point reef pattern resembles that seen in the lagoons of the Maldives in the Indian Ocean today [32], though on Anticosti there is no evidence for a protective back-reef barrier in any direction. However, reef tops and flanks show breakage of large coralla and stromatoporoids and reef rubble in the Box River-Dauphiné area, suggesting that these were in shallower waters of the inner shelf, more affected by storms and tidal currents. None of the reefs grew into the shallowest subtidal zone: no storm channels, spur and groove structures, or erosional discontinuities were evident, as such are seen in the much younger Chicotte reefs of Anticosti [33].

Reef bases appear to have been generally flat-bottomed, as seen in road outcrops and coastal bluffs. Reefs appear to have been too small to produce depressions in the underlying carbonate basal beds, such as the 'philip structures' seen in the late Llandovery of Gotland, Sweden.

\section{Reef Builders and Carbonate Re-Cyclers}

The East Point reefs show a mixed fabric produced by frame-building constructors, encrusting and binding skeletons, bafflers, and interstitial sediment, primarily of carbonate silt to sand grade. Coarse reef rubble fabric (rudstone) was developed along the margins by storm-reworked carbonate-secreting builders, and fine to coarse-grained carbonate sediment (siliciclastics are absent). Some of the clasts were deposited between the builders in a mix of fine "polymud" to sand-sized fragments: cavities were infilled by layers of fine sediment, including peloidal grains, and a few show encrusting cryptic biota (bryozoans or enigmatic biota) that were suspended from cavity roofs. Cryptic "lithistid" demosponges, displaying internal spicules, were attached to the sides and in the cavity space between branching rugosans. Endosymbiont embedment structures (bioclaustrations, such as Chaetosalpinx and cornulitids) and borings (bio-eroders) were a common feature in the reef biota, but usually in the denser domal skeletons. Indeed, borers were more intense in off-reef stromatoporoids, producing a "Swiss cheese" fabric [7]. Intimate intergrowths of stromatoporoids with rugose corals such as Palaeophyllum were also a feature first seen on Anticosti in the East Point reefs at Box River [7].

Quantitative estimates of the various components are in general difficult to obtain (a) since almost every reef demonstrates different dominant components and fabrics, (b) such components vary through the reef from base to top or from core to flanks, and (c) for the smaller components, the percentage volume varies from thin section to thin section, and even within thin section, or from slab to slab. The East Point reefs cannot be classified as "mudmounds", as muddy fractions formed only a very small part $(<3-5 \%)$ of the reef fabric as a whole. Cavities and reef interstices of the reef core and flanks usually remained unfilled by contemporaneous or post-depositional cement; thus the East Point reefs are generally cement-poor. The East Point reefs also differed substantially from the younger Chicotte diagenetic, mud-dominated, bryozoan-sponge 'buildups' [34]. Interstitial fabrics of the remaining lower and upper Chicotte reefs are also different, being largely dominated by crinoidal grainstones and 
show common radial-fibrous cement (instead of abundant cavity space as in the East Point reefs), and more abundant East Point microbial and sponge encrusters (see Figure 6a,b, in the dark micritic crusts around Entelophyllum). East Point reefs have little in common with the older, Hirnantian Laframboise reefs of Anticosti in their biota, and they featured less calcimicrobial fabric such as Girvanella, seen in the Ellis Bay Formation, and lacked the common Ellis Bay red alga Solenopora. The East Point reefs also had no basal oncolite platform bed.

\section{Reef Constructors}

The East Point reefs were primarily constructed (1) via the upward individual growth of large (40 cm in diameter) coral skeletons, such as the overall domal forms of large cerioid Favosites, cateniform Cystihalysites, the aphroid rugosan Palaearaea, or phaceloid rugosan Entelophyllum (proportions differing in almost every reef, but primarily in reef tops and flanks), and (2) by vertical and lateral stacking of layers of smaller overgrown corals and stromatoporoids. These commonly roofed over cavities between the stacked skeletons or between adjacent intergrown skeletons. Mutlisolenia is relatively common, but formed small-sized colonies ( $<10 \mathrm{~cm}$ in diameter) in the East Point reefs. The bases of the reefs were established, where this could be determined, on meadows of crinoids, or a hash of broken small Catenipora and especially small syringoporids. Thus the term 'coral patch reef' would be the most appropriate description.

\subsection{Corals}

The rugose coral faunas of the East Point Member (and other Silurian rugosans) of Anticosti are under revision [29]. Included are seven species of solitary and four colonial rugosans (including one new genus), nearly all of which lived in the reef, or biostrome facies. Bolton [17] first figured a specimen of Entelophyllum wahlenbergi (Billings, 1862) [35] from the type locality at East Point. Entelophyllum was one of the dominant frame builders of the reefs for size and quantity, as colonies reached diameters of 70-100 $\mathrm{cm}$ (Figure 6a,b). Solitary rugosans were anchored by holdfasts to skeletal substrates of stromatoporoids or calcimicrobes, or were overgrown by these post-mortem, but were not abundant in volume. The solitary corals include some ten genera: Helicelasma, Kodonophyllum, Phaulactis, Pseudophaulactis, Cyathactis, Rhabdocyclus, Cantrillia, Chaloupella, Rhegmaphyllum, and Cystiphyllum, some of these representing their first known Early Silurian records. The Siberian aphroid genus Palaearaea was the first known occurrence of the genus outside Russia. Its solitary counterpart Calostylis occurs some $50 \mathrm{~m}$ below the reefs.

Tabulate corals are thus far taxonomically unstudied: herein we include the first illustrations, but no comprehensive coverage of taxa (Figures 6 and 7). Many intergrew with stromatoporoids. Tabulates are volumetrically more common in the biostromal facies, and within the reefs they were usually less common domal or encrusting forms. Most were small $(<10 \mathrm{~cm}$ diameter), except for Favosites and Cystihalysites (Figures 6f and 7e) that reached diameters of $40-50 \mathrm{~cm}$, and for the latter, occasionally heights of $c a .60 \mathrm{~cm}$ (in the reefs around the Box River). We have here the first Anticosti records of Pycnolithus, Subalveolites, Placocoenites and Multisolenia. Pycnolithus is an encrusting heliolitid, deceptively stromatoporoid-like, with very dense skeletons, and minute corallite cavities (Figure 7e). Pycnolithus occurs also in the underlying upper Goéland (Figure 7g) and overlying basal Richardson 
Member: its previously known first occurrence is from the basal Sheinwoodian Upper Visby strata of Gotland [36]. Multisolenia, is a common East Point patch reef inhabitant (Figure 6g), that makes its first appearance in the Rhuddanian Merrimack Formation. The tabulate genera Subalveolites, and Placocoenites first appear in the East Point Member of Anticosti (in Baltica, the oldest are from late Telychian rocks of Estonia). Small clusters and colonies of Catenipora (Figure 8d) and Syringopora (Figure 9c) commonly make the reef foundations alongside skeletal debris of crinoids and brachiopods. The small domal heliolitid Propora is scattered throughout the reef setting as coralla of $<10 \mathrm{~cm}$ diameter, and $<7 \mathrm{~cm}$ height (Figure 6e,f). Many of the tabulates intergrew or overgrew other corals, calcimicrobes or stromatoporoids (Figure 6e). Striatopora makes itself first known in the late Telychian of Anticosti (it is absent in the East Point Member), whereas in Estonia its oldest occurrence is in the Wenlock. Coral and stromatoporoid recovery from storm damage was repetitive and frequent, with growth interruptions commonly defined by calcimicrobial crusts (see Figures 6d,g and 7a,d).

Figure 6. Coral framework of the reefs. $(\mathbf{a}, \mathbf{b})$ transverse and longitudinal sections of the volumetrically abundant Entelophyllum wahlenbergi (Billings, 1862). Note black calcimicrobial crusts, enclosing rare sponge spicules, around corallites, spar- and carbonate sand-filled cavities, and intracalicular budding in this spreading corallum (GSC129570, locality A1275); (c) broken solitary coral covered by Clathrodictyon lenticulare and calcimicrobial crust (locality A1196); (d) solitary rugose coral attached to a base of Petridiostroma, and Clathrodictyon, in turn covered by black microbial crust, and an overarching Clathrodictyon leaving a cavity underneath (GSC127849, locality A1275); (e) successive stacking of the tabulate coral Propora (base), calcimicrobial crust, cavity, Petridiostroma and another Propora (GSC125470, locality A1489); (f) chain coral Catenipora encrusting heliolitid, with calcimicrobial crust and sediment infill (GSC125463, locality A1489); (g) storm-disrupted favositid coral Multisolenia with calcimicrobial crust and cavity and regrowth of same corallum above (GSC127859, locality A703).

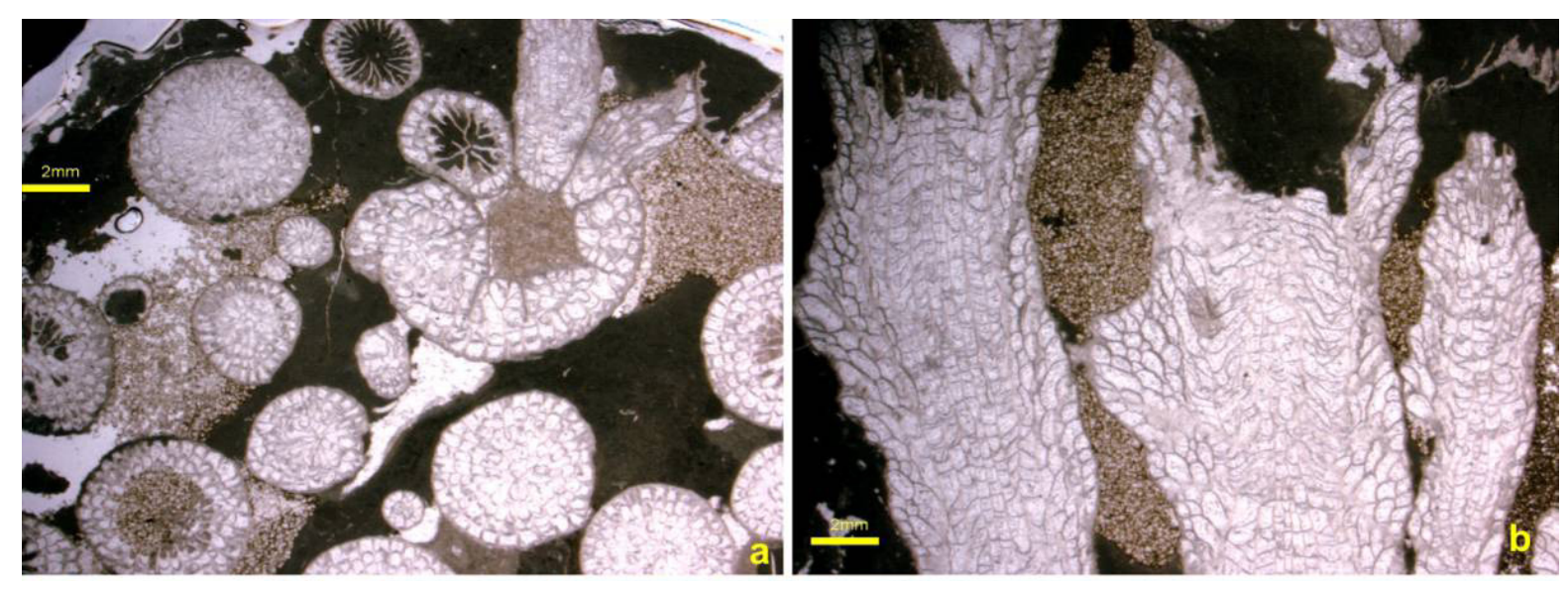


Figure 6. Cont.

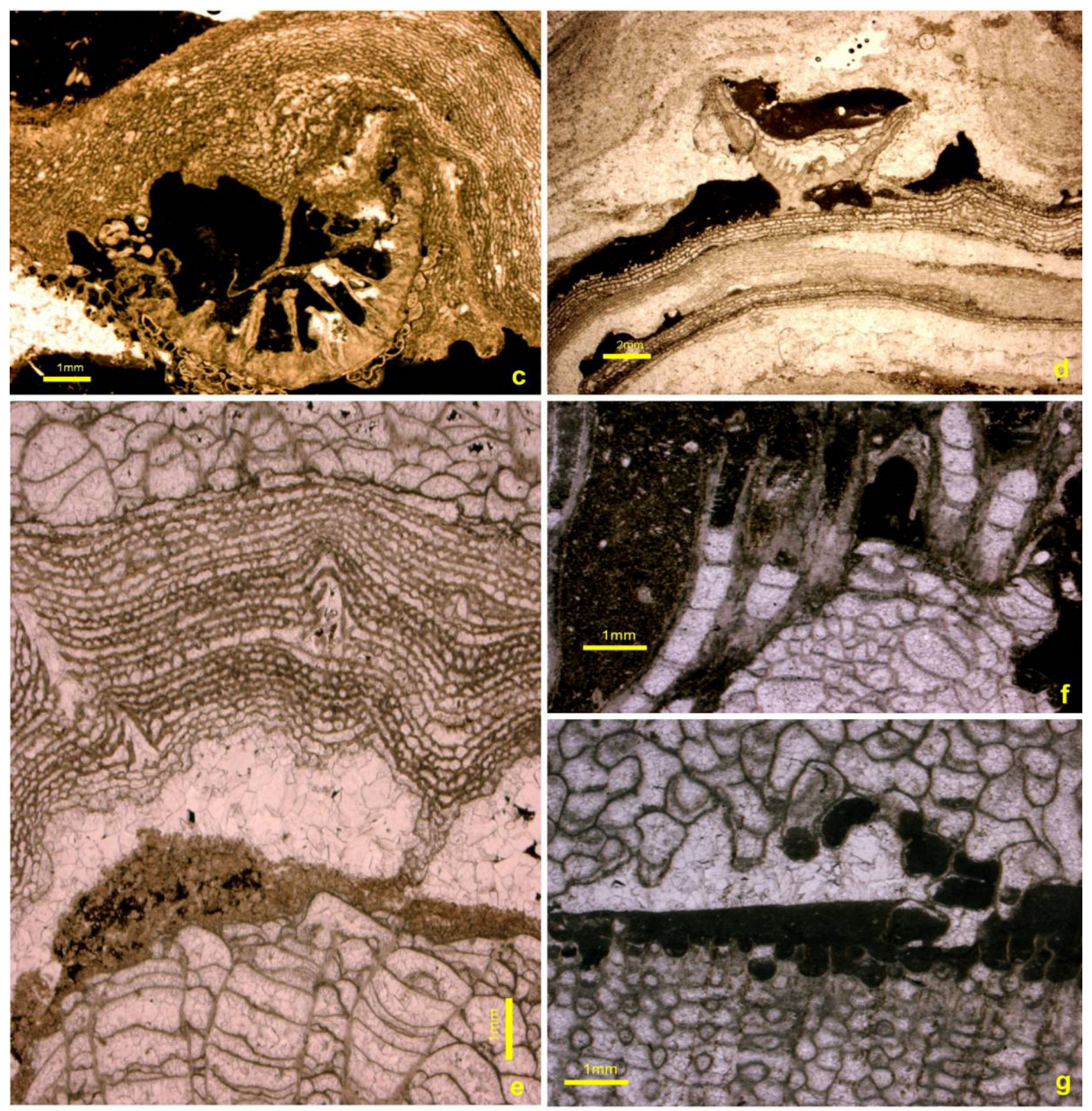

\subsection{Stromatoporoids}

The stromatoporoids of the East Point reefs and biostromes include six genera and nine species, nearly all of which are confined to the reefs or biostromes. These include the genera Clathrodictyon with two different species (Figure 7a,b), Ecclimadictyon, Forolinia (Figure 7d), Petridiostroma, Tarphystroma, and Camptodictyon [7]. None were major reef builders, and nearly all are small in size, rarely more than $10-15 \mathrm{~cm}$ in diameter or height. Petridiostroma occurs only as rare, very thin $(<1 \mathrm{~cm})$ encrustations on top of or between other reef builders (Figures 6e and 7f). Tarphystroma is rare: only a few specimens were collected (Figure 7c), but they were significant encrusters and binders when present. Species abundance varied by locality. Most common were Clathrodictyon, Ecclimadictyon and Forolinia. Forolinia and Tarphystroma had very dense skeletons, with almost no vacant space within skeletons: some of these were bored by Chaetosalpinx or Trypanites (Figure $7 \mathrm{~g}$ ), or intergrown with cornulitids [7]. Very dense skeletons presumably marked slower reef-builders, such as the 
stromatoporoids Forolinia (Figure 7d), and Tarphystroma (Figure 7c), and the platy encrusting tabulate coral Pycnolithus (Figure 7g). Relatively lighter or more porous stromatoporoid skeletons were probably more rapid builders: Clathrodictyon and Ecclimadictyon, for example, produced greater pore space within the skeleton.

Figure 7. Dense reefal stromatoporoid and coral skeletons. (a) successive platy to weakly domal encrusting stromatoporoid Clathrodictyon lenticulare from middle to upper reef sequence capping sediment, encrusted by 'spongiostromate' crusts, making cavity space (GSC125412, locality A1489); (b) irregular growth of Clathrodictyon sinuosum with interstitial silty carbonate and calcimicrobial crusts, cavities, usually in basal reef portions (GSC128412, locality A1188); (c) dense skeleton of reef-adapted Tarphystroma found in reef tops and flanks (GSC127868, locality A1275); (d) biostromal occurrence of dense Forolinia, storm-disrupted, then settled by the heliolitid coral Propora?, capped by Clathrodictyon (GSC127834, locality A1293); (e) intergrowth of the tabulate corals Catenipora (at base), Pycnolithus (middle and top) and Paleofavosites (above) from a biostromal setting (GSC128040, locality A1293); (f) storm disrupted top of tabulate coral Propora: see broken, detached calice, calcimicrobial crust, carbonate grains (GSC128403, locality A863); (g) Pycnolithus skeleton encrusting pentamerid shell and intergrown with the stromatoporoid Petridiostroma (GSC128024, A1297c, upper Goéland Member); (h) symbiont phaceloid rugose coral Palaeophyllum intergrown with stromatoporoid Clathrodictyon (GSC127806, A1196; diameter of corallite $=3 \mathrm{~mm}$ ).
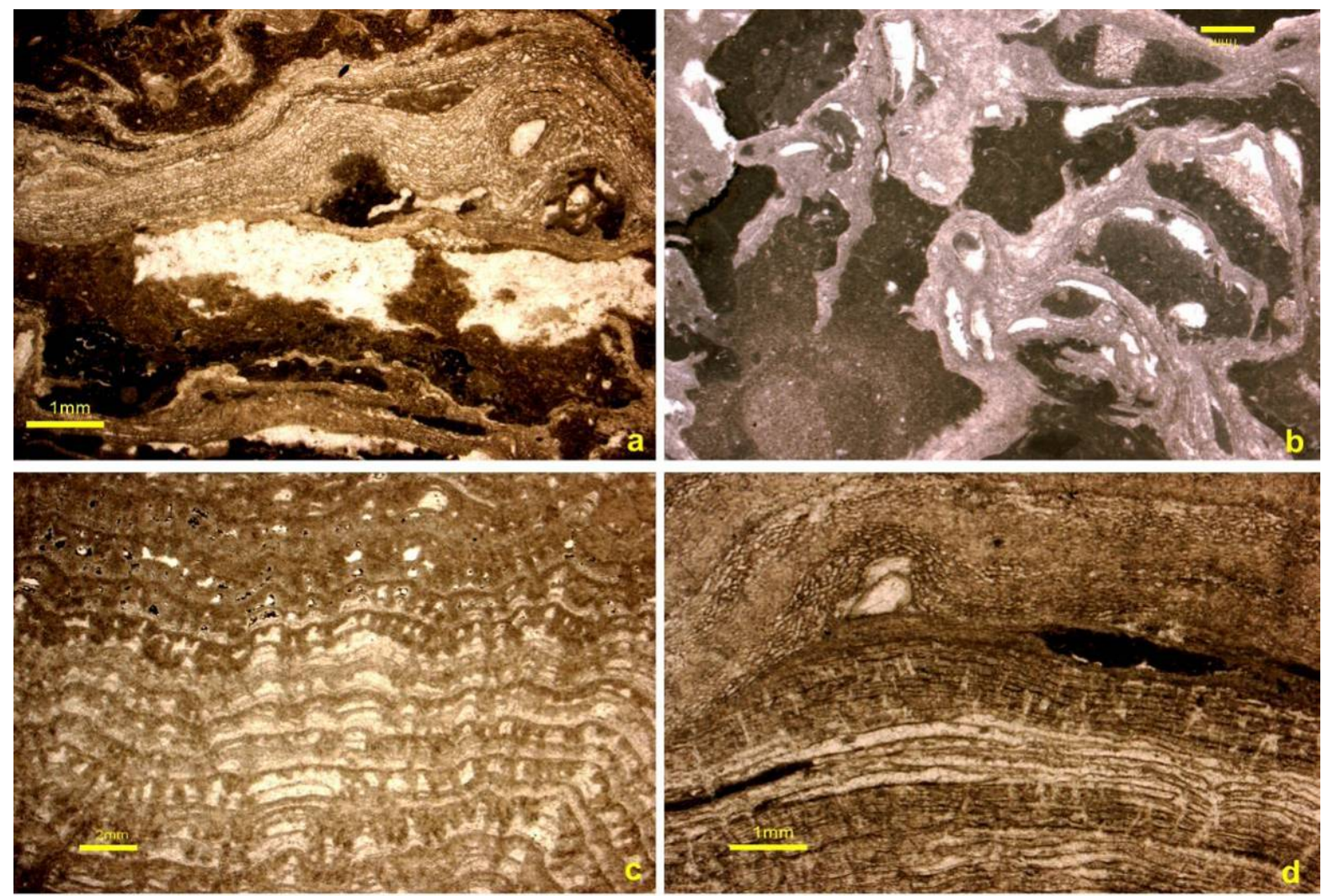
Figure 7. Cont.
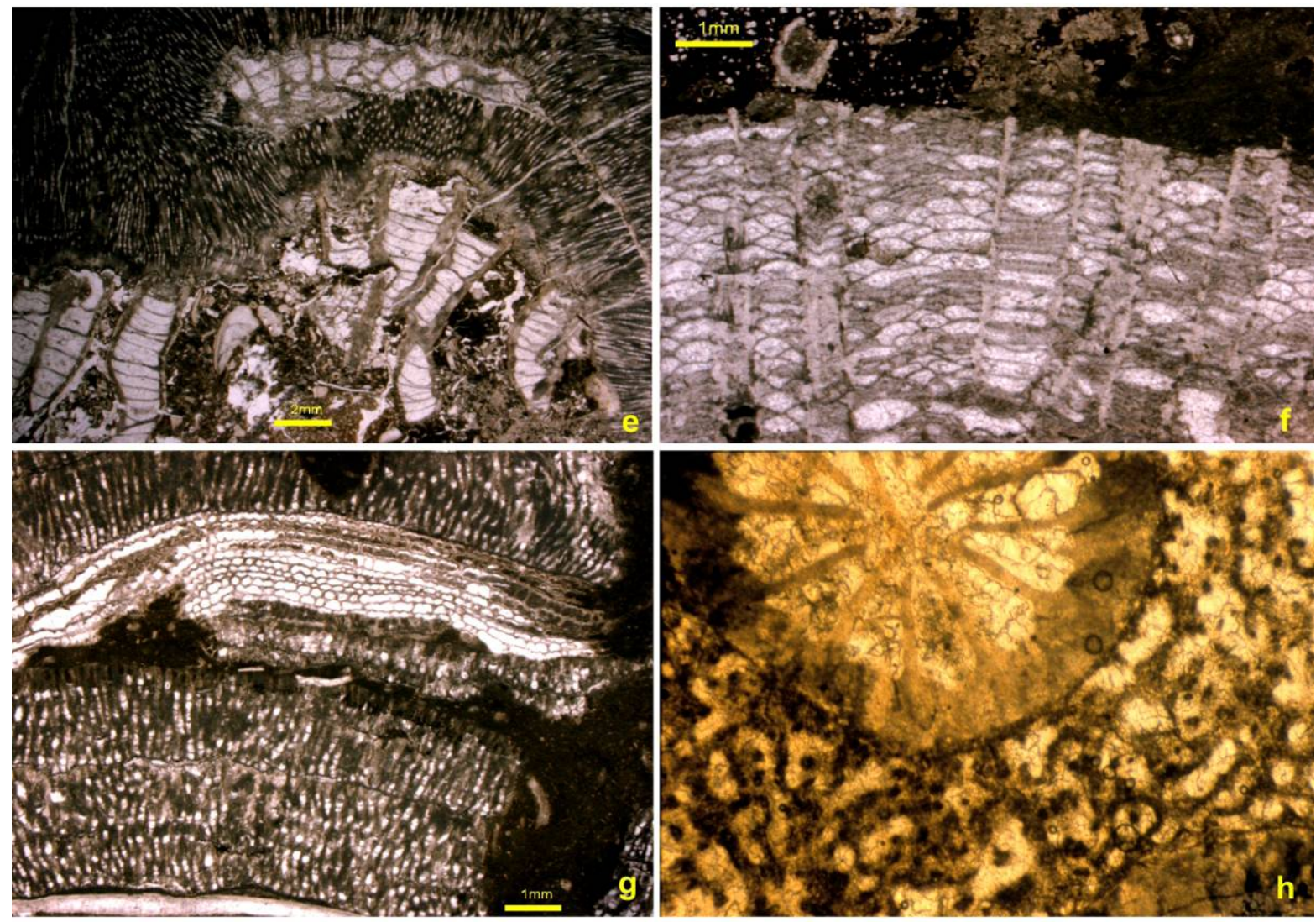

\subsection{Cavity Structures and "Stromatactis"}

Common elements in reef fabric of the East Point reef cores were cavities. These were either (a) smaller cavity spaces left between or underneath overhanging coralla and stromatoporoids (Figure 6), or (b) large cavities up to 30-60 cm across and 30-40 cm high. These were best seen in polished slabs (Figure $8 \mathrm{c}-\mathrm{h}$ ), or in thin sections from reef cores (Figure 9). Inside the larger cavities the most distinctive are the controversial "zebra rock" or "stromatactis" structures. In this study, zebra rock was found only in existing reef cavity spaces, and consists of multiple layers of sediment infill, and the presence of cement-filled cavities above each level, producing dark (cement-filled) and light fine sediment layers. Sediment layers were (a) commonly horizontal or subhorizontal (Figure 8c,e,f), (b) irregular or curved to meet cavity space (Figure 8d,g,h), or (c) consisted of broken-up firm or weakly cemented layers (Figure 8a,d).

The deciding factor for the shape of the 'stromatactis' structures was the original shape of the cavity, or the skeletons that formed the cavity itself. Some of the sediment layers, generally fining upwards from silt to mud-size carbonate in each layer, consisted of peloidal accumulations surrounded by cement. Elsewhere, 'stromatactis' has been attributed to many processes, as variable as secondary diagenetic features, or remnants of collapsed soft sponges in mudmounds [37]. In the East Point reefs, those two mechanisms do not seem feasible, as the East Point reefs were formed in shallow waters above wave base, and were not mudmounds. 
Figure 8. Reef core cavity formation, infill and "stromatactis" structures from polished slabs. (a) longitudinal polished slab view of the rugose coral Palaearaea forming an adjacent cavity with cavity sediment fill (right side, width of field $=25 \mathrm{~cm}$ ); (b) aphroid Palaearaea, a major reef former, in surface view (scale bar $=1 \mathrm{~mm}$; colony width $=15 \mathrm{~cm}$, GSC125361); (c) reef cavity formed by calcimicrobial mound growth of Wetheredella, Girvanella and Rothpletzella (lower left side), followed by crinoid holdfasts forming a "roof", and then successive cavity infill by sand to silt to mud-sized sediment, and remaining empty space filled by post-depositional; cement (upper left; width of slab $=15 \mathrm{~cm}$ ); (d) basal reef core cavity infill and formation-crinoids and syringoporid formed the cavity space, repeatedly broken by storm action and re-infilled over several seasons; (e) and (f) "stromatactis" cavity fill structures in reef core marking successive infill by silt to mud-sized carbonate sediment, early cementation forming a roof to the cavity (later infilled by sparry calcite) and probable seasonal cycles, $(\mathbf{e}$, width $=15 \mathrm{~cm}$; $\mathbf{f}$, width $=5 \mathrm{~cm}$ ); (g) irregular "stromatactis" formed by roofed over Paleofavosites and successive cavity infills and sparry cement (width of slab $=5 \mathrm{~cm}$ ); (h) irregular 'stromatactis' cavity infill underneath alveolitid corals.
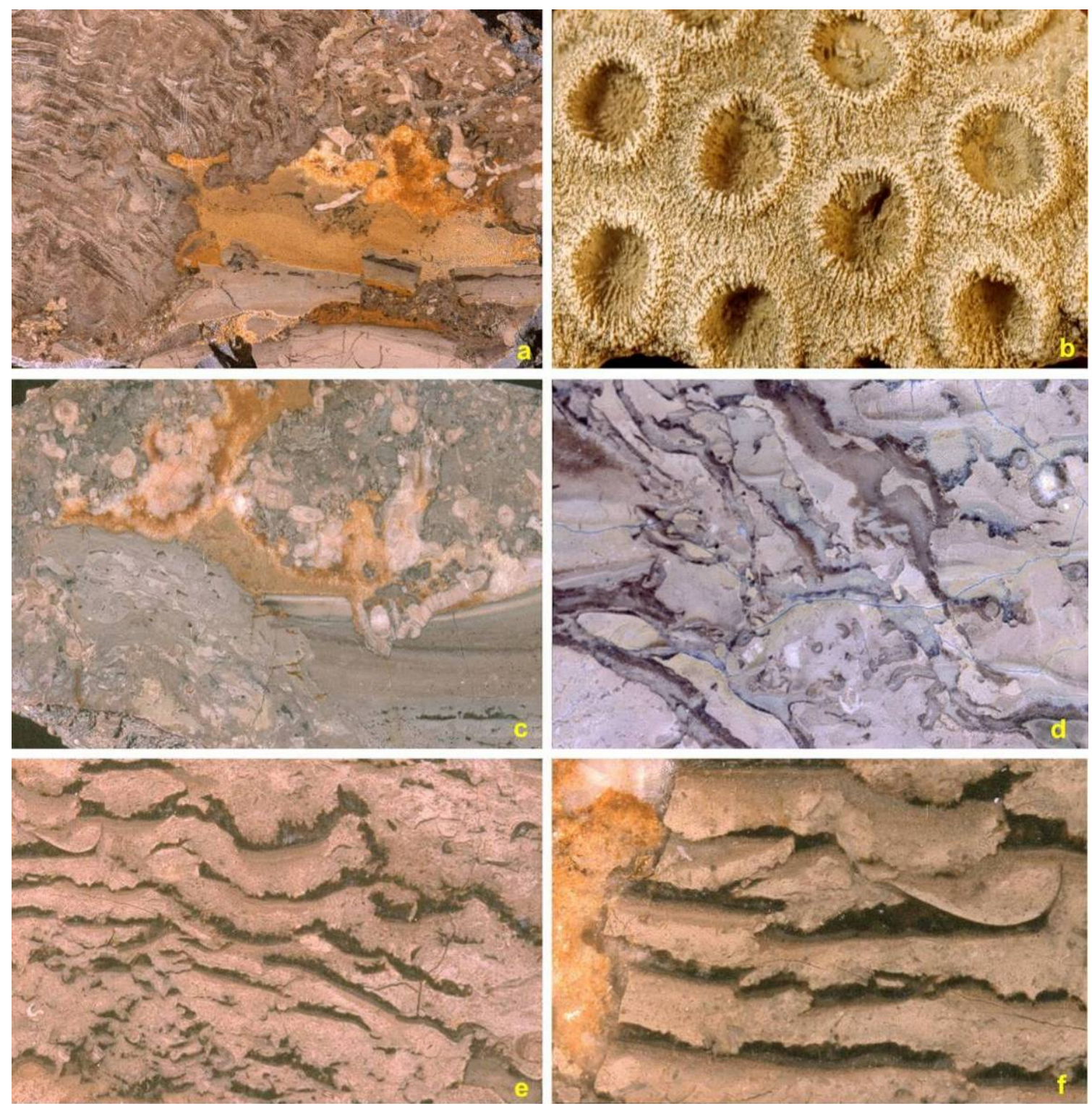
Figure 8. Cont.
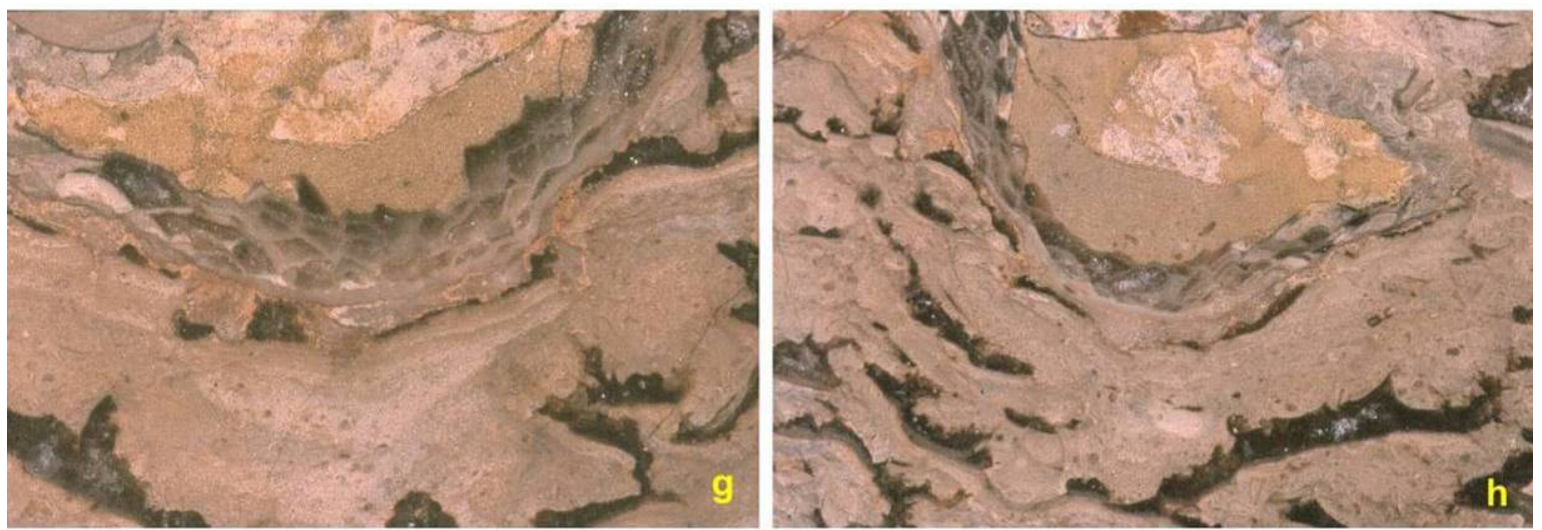

\subsection{Binding and Encrusting Microbial Biota}

Unlike the late Hirnantian reefs of the Laframboise Member in the Ellis Bay Formation [31], the proportion of calcimicrobial crusts or binders was generally less important, estimated at 5-20\%, in the East Point reefs. The calcimicrobe Wetheredella is the most readily identifiable encrusting cover on corals (Figure 9d,e), stromatoporoid sponges, or crinoid holdfasts (Figure 9). Rothpletzella and Girvanella were less common (Figure 9f), though in patches forming solid crusts up to centimeters thick (Figure 9g). This is different from the Hirnantian reefs of Anticosti, where calcimicrobes locally make up to $40-60 \%$ of the reef fabric, and where oncoids were made by encrusting Girvanella.

Less clearly recognizable are problematic 'Spongiostroma' crusts that occur as dark brown to nearly black, irregular crusts surrounding other skeletons (Figure 6a,b). Some of these contain abundant minute sponge spicules or sclerites, and may thus be of poriferan origins (Figures $7 \mathrm{a}, \mathrm{b}$ and $9 \mathrm{e}$ ). These probably formed after seasonal or storm damage on some stromatoporoid surfaces, and were covered by succeeding stromatoporoid growth (Figures 6d,e,g and 7a,e,g). The most common microbial component appears to have been a dark brown to almost black, micritic, microbial cement that wrapped itself around corals, stromatoporoids and bryozoans, leaving cavity spaces (Figures 6a,b,d,g and 7g). This micritic "microbial cement" may be the most common identifiable microbial infill. Some of these crusts may be remnant fossilized demosponges that grew attached to the sides of corals, as occasionally spicules are locked into the dark shaded fabric (Figures 6a,b and 9c).

\subsection{Bafflers}

The most prominent bafflers in the reefs were the crinoids that attached their holdfasts to the reef framework, and whose roots commonly formed overhanging cavities (Figures 8c,d and 9c), sometimes filled by "stromatactis" layers. As both Inter-reef crinoid meadow formers, and intra-reef dweller inhabitants, the crinoids [38] were volumetrically abundant, making up almost $95 \%$ of the meadows (crinoidal grainstones) and probably close to $20 \%$ of reef volume. In the reef eco-space, and attached with holdfasts to corals or stromatoporoids, were the genera Eumyelodactylis, Hormocrinus, Fibrocrinus and Ladacrinus (the latter two thus far known only from the East Point Member).

Green algae, e.g., Paleoporella (Figure 10d,h) were common as a reef base component, sometimes covering surfaces of thin beds in masses (Figure 10h). Gauthier-Coulloudon and Mamet [39] identified 
as sketch illustrations a host of cyanobacteria and algae from Anticosti, but evidently did not examine any East Point reef material, unless some of their material labeled as 'Gun River' or 'Jupiter' belonged to East Point reefs. At present, it is not clearly understood why red algae, such as Solenopora, so abundant or common in Hirnantian reefs of Anticosti, were entirely absent from the East Point reefs.

Figure 9. Micrographs of microbial reef fabrics. (a) tangential view of 'Ptestia' a possible coccoid calcimicrobe, associated with the tubular calcimicrobe Wetheredella (width of view $=2 \mathrm{~mm}$, A1198); (b) coccoid 'Ptestia' attached to Syringopora corallite base and capped by Wetheredella (width of view $=2 \mathrm{~mm}$, A1198); (c) coccoid 'Ptestia' encrusting and covered by the fine tubular calcimicrobe Girvanella and reinforced cavity cement (width of view $=4 \mathrm{~mm}$, A1203); (d) encrusting Wetheredella attached to a recumbent Syringopora corallite and completely enveloped in a calcimicrobial spongiostromate casing (width of view $=4 \mathrm{~mm}$, A1198); (e) encrusting Wetheredella in fabric of Rothpletzella (width of view $=4 \mathrm{~mm}$, A1196); (f) dominant encrusting Girvanella fabric with rare Wetheredella (width of view $=2 \mathrm{~mm}, \mathrm{~A} 735$ ).
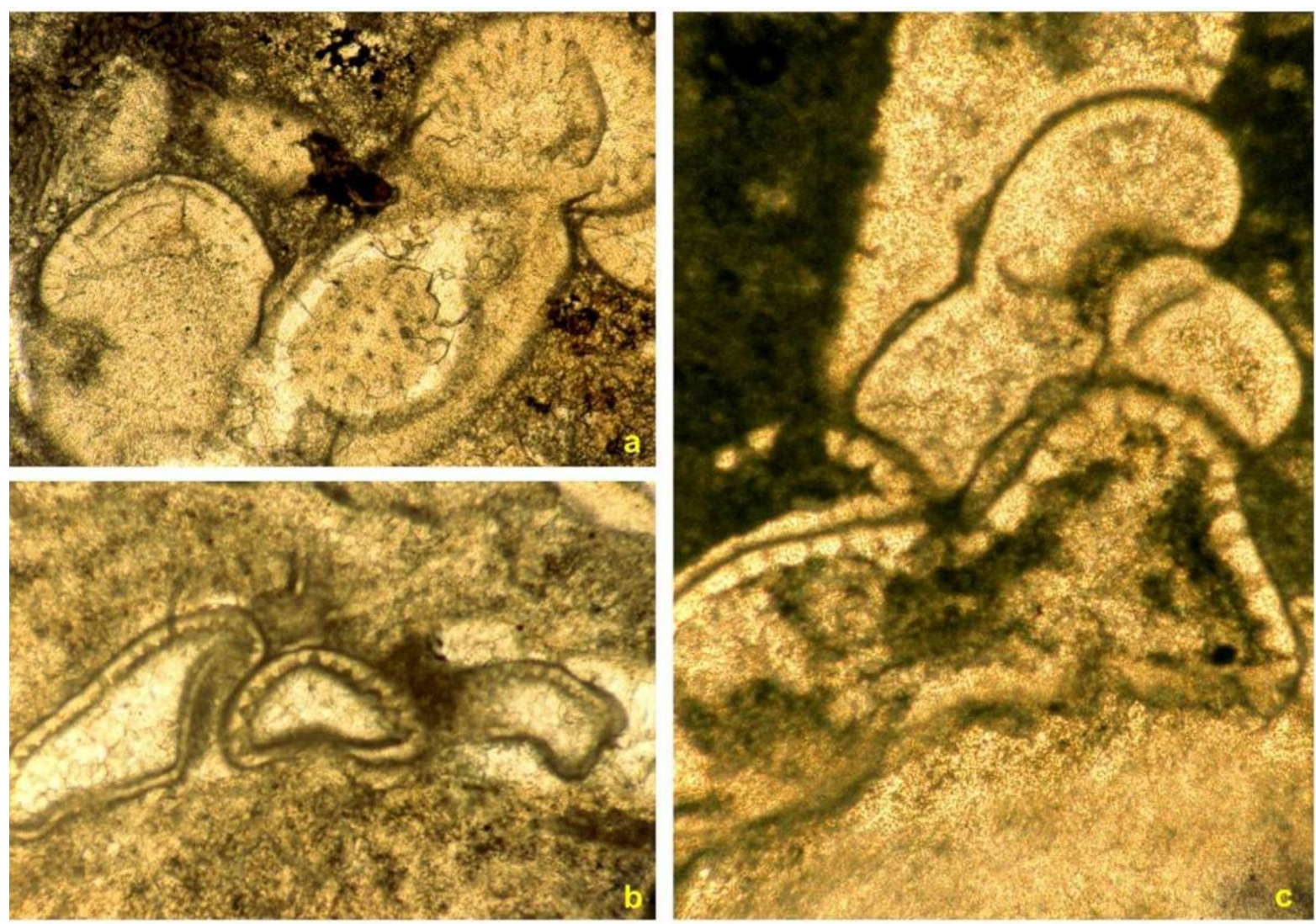
Figure 9. Cont.
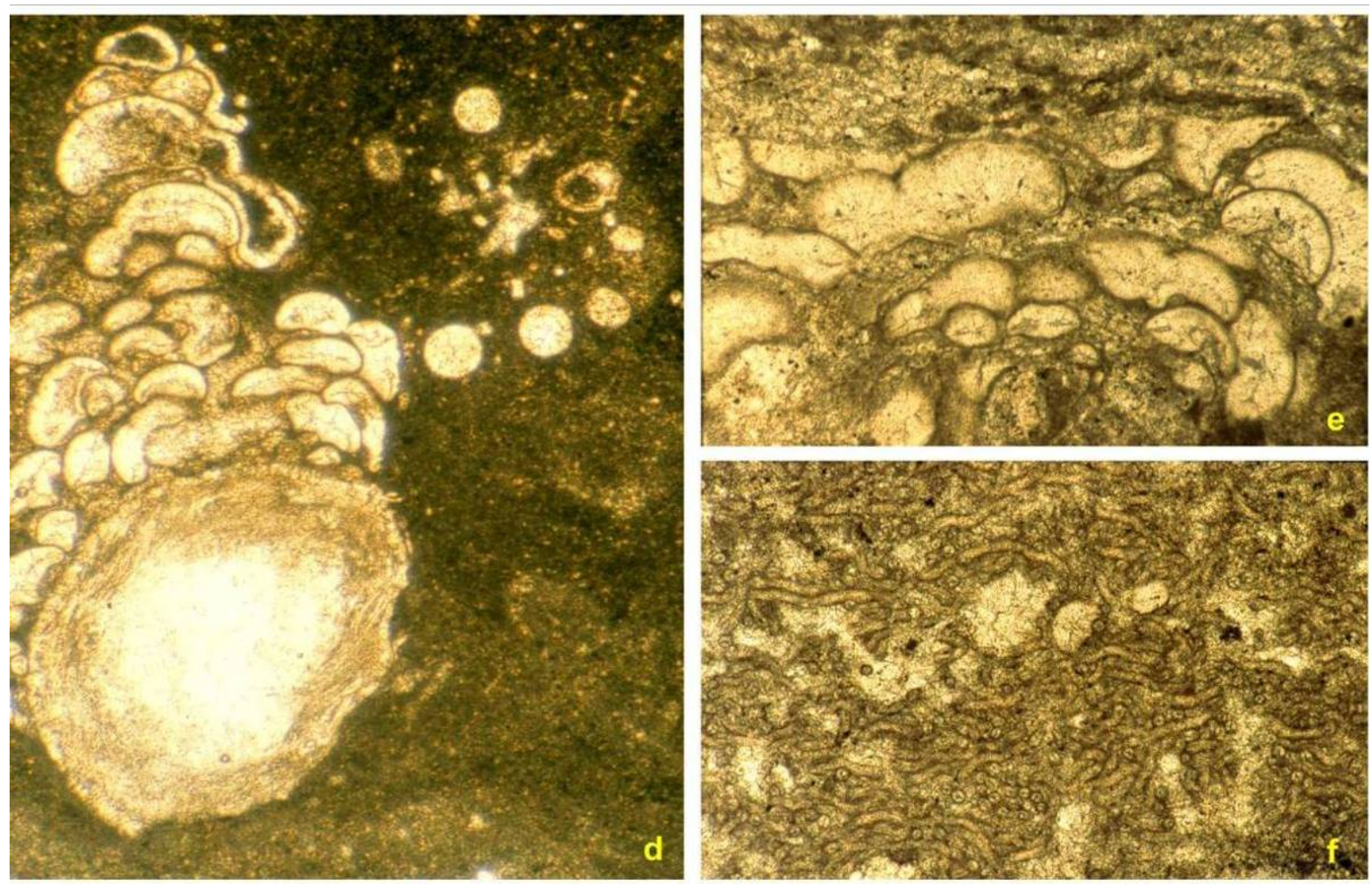

Figure 10. Reef initiators. (a) encrusting bryozoan common in basal reef layers (GSC125462, locality A1198); (b) multiple platy bryozoans in basal reef layers roofing over cavities (GSC129915, locality A1489); (c) domal bryozoan from reef core (GSC128040, locality A1293); (d) basal reef layers with clast-forming recrystallized chlorophyte Paleoporella (GSC128659, locality A1489); (e) multiple layers of very thin, roofed and stacked from base up, platy bryozoan, encrusting corals such as Placocoenites (middle) and at top, Subalveolites (GSC128659, locality A1489); (f) Trypanites borings in reef framework (GSC128660, locality A1198); (g) encrusting tabulate coral Subalveolites and reef sediment, cavities (GSC128660, locality A1198); (h) basal reef hash of recrystallised Paleoporella (GSC128667, locality A1496).
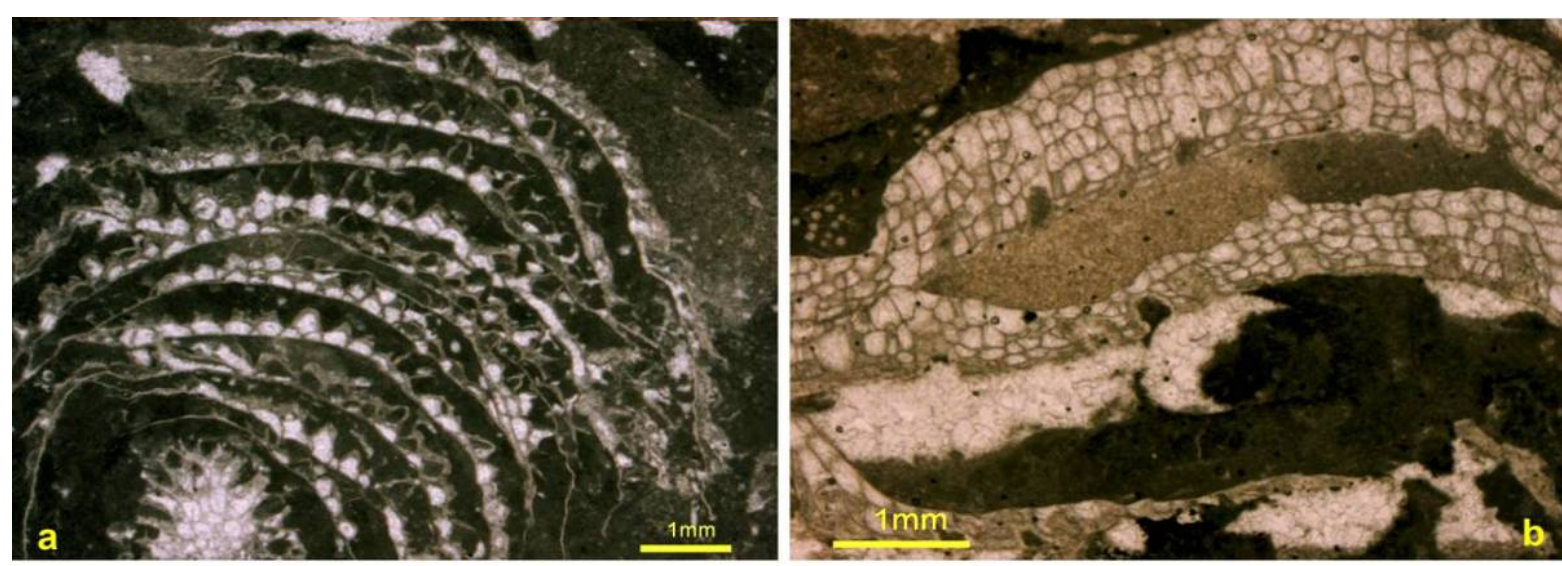
Figure 10. Cont.
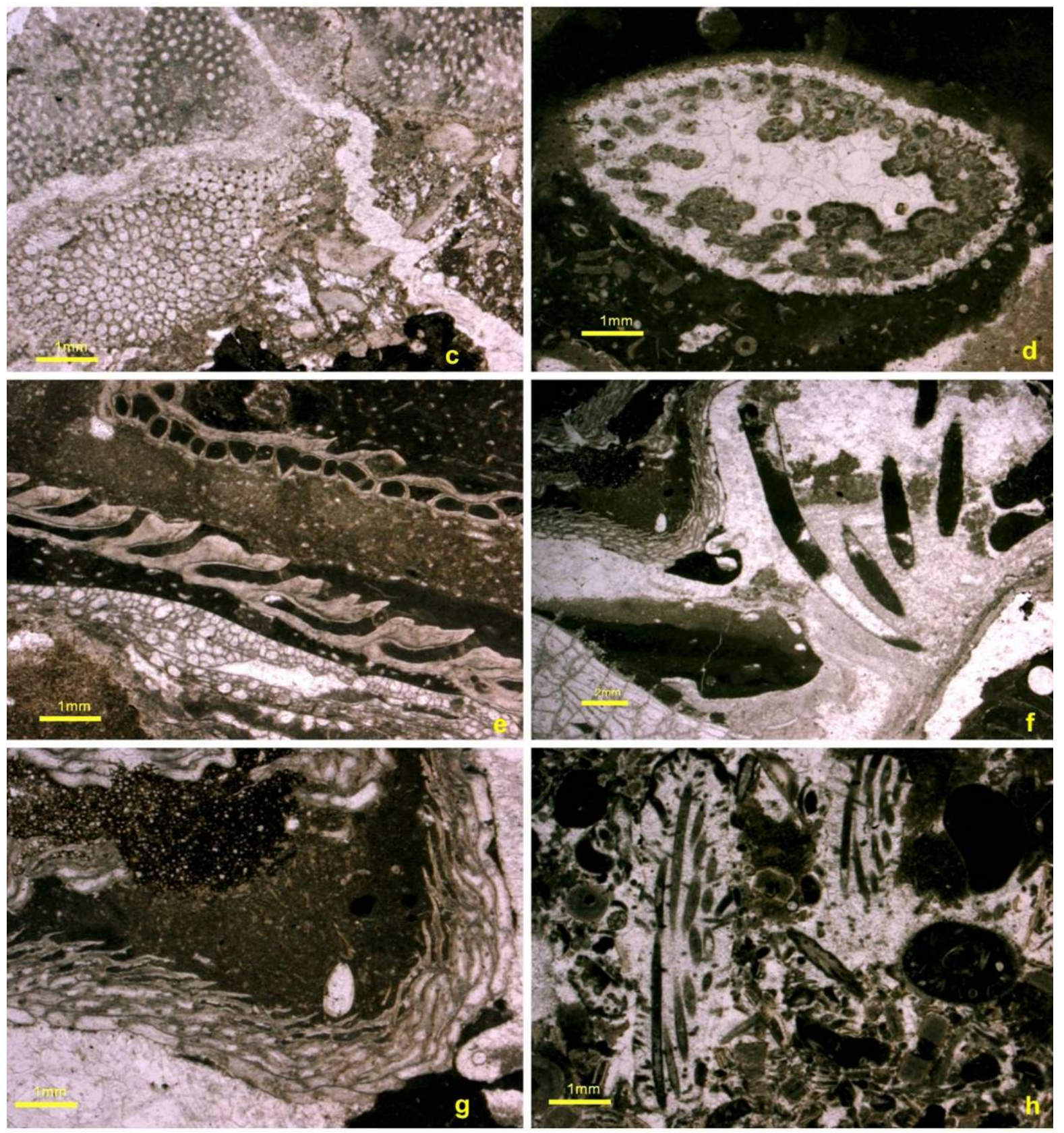

\subsection{Reef Dwellers}

Other than the main constructors, bafflers and binders, crinoids and brachiopods were locally common constituents, though volumetrically $<3-5 \%$. Brachiopods were generally small-sized within and adjacent to the reefs, such as Dihelictera, Septatrypa, aGotatrypa, and Stegerhynchus, the last sometimes making whole shell beds just below the reefs. The occurrence of the large-shelled pentameride brachiopod genera Pentamerus and Mircocardinalia were sporadic, usually disarticulated and broken valves within the reef but not uncommon in the down-slope biostromal or crinoidal grainstone facies of the East Point Member. A yet undescribed species of Anastrophia in the East Point reef facies (locality A863) is the oldest known representative of the genus, extending back the 
previously known range of Anastrophia by about 10 Ma. Trilobites and ostracodes occur as disarticulated minor components $(<1 \%)$, or as broken fragments, recognizable only in thin section.

Bryozoans have not yet been taxonomically labeled. Unidentified examples are shown (Figure 10), most of which are encrusters, but a few occurring as isolated upright elements. A common type is a serial encruster consisting of thin, domed sheets (Figure 10a). Flat sheet-like encrusters were attached to other skeletons or covered sediment layers (Figure 10b,e). Some small marble to golf-ball bryozoans are present (Figure 10c). Boring organisms were unexpectedly rare in the reef setting (Figure 10f). Angular to rounded rip-up clasts in the basal reef layers, as well as reef core and flanks, indicate there may have been local hardgrounds providing reef sediment (Figure 10h).

\section{Conclusions: What Triggered Reef Growth?}

The East Point reef bases occur as outcrops at relatively few localities, and reef foundations were variable from reef to reef (as were the major reef builders). In some instances, the basal components did not lead to reef growth. Where the reef bases were exposed, they consisted of variable clasts ranging from crinoid ossicles (maybe the most common reef base), brachiopod shells (Stegerhynchus being most common), paleoporellids (Figure 10h), or tabulate coral hash of Catenipora (Figure 6f), and Syringopora. (Figure 9c). In the shallower water areas of the East Point facies at the northern edge of the outcrop belt these resulted in reef growth in deeper water facies to the south biostromes resulted, and the member thinned to $<1-2 \mathrm{~m}$.

In terms of environmental controlling factors, the reef-building intervals in the Upper Ordovician-Lower Silurian succession of Anticosti Island show a broad correlation with episodes of sealevel fall and marked positive excursions of $\delta^{13} \mathrm{C}$ and $\delta^{18} \mathrm{O}$ excursions [40]. On Gotland, a similar correlation between reef-building and positive $\mathrm{C}$ and $\mathrm{O}$ isotope excursions has been noted for the Wenlock and other horizons, which led to the observation that, in the Silurian low paleolatitude, periods of such positive isotope excursions are characterized by the growth of reefs and the formation of extended carbonate platforms [41,42]. It remains debatable if, during a general supergreenhouse climate of the Late Ordovician-mid Silurian, relative cooling (e.g., Hirnantian and Sheinwoodian glaciations) could create optimal conditions for reef growth in tropical latitudes by: (1) lowered super-heated ocean water temperature; (2) a drier tropical climate; (3) improved ocean circulation due to strengthened downwelling and psychrospheric flow generated around ice-capped polar regions; and (4) lowered sealevel encouraging shallow reef growth. On the other hand, increased phytoplankton production with nutrient upwelling during cooler episodes (triggering black organic-rich shale formation, as in the Calvert-Pedersen model) might have constrained reef size and distribution in the Hirnantian. Organic rich graptolitic shales of the deeper water Richardson Member cap the East Point reefs, and mark their demise. It is notable that in many areas worldwide, the Hirnantian, such as in the stratotype section of the O/S boundary at Dob's Lin, is marked by organic rich black shales. These are absent at the $\mathrm{O} / \mathrm{S}$ boundary section of Anticosti.

\section{Acknowledgments}

Jean Dougherty of the Geological Survey of Canada (Ottawa) kindly arranged the storage and loan of specimens for this study. Both authors thank the Natural Sciences and Engineering Research 
Council of Canada for consistent field, laboratory and student support over many years. The critical and constructive comments of Axel Munnecke and three other journal reviewers greatly helped improve the clarity of our discussions.

\section{References}

1. Ghienne, J.F. The Late Ordovician glacial record: State of the art. In Ordovician of the World; Gutiérrez-Marco, J.C., Rábano, I., García-Bellido, D., Eds.; Cuadernos del Museo Geominero, Instituto Geológico y Minero de España: Madrid, Spain, 2011; Volume 14, pp. 13-19.

2. Caputo, M.V. Ordovician-Silurian glaciations and global sea-level changes. N.Y. State Mus. Bull. 1998, 491, 15-25.

3. Diaz-Martinez, E.; Vavrdova, M.; Isaacson, E.; Grahn, C.Y. Early Silurian vs. Late Ordovician glaciation in South America. In Ordovician of the World; Gutiérrez-Marco, J.C., Rábano, I., García-Bellido, D., Eds.; Cuadernos del Museo Geominero, Instituto Geológico y Minero de España: Madrid, Spain, 2011; Volume 14, pp. 127-134.

4. Copper, P. 100 million years of reef prosperity and collapse: Ordovician to Devonian interval. In Corals and Reefs: Crises, Collapse and Change; Stanley, G.D., Ed.; The Paleontological Society Papers; Volume 17, pp. 15-32.

5. Copper, P. Upper Ordovician and Lower Silurian reefs of Anticosti Island, Quebec. In Reefs, Canada and Adjacent Areas; Geldsetzer, H.H.J., James, N.P., Tebbutt, G.E. Eds.; Memoirs Canadian Society of Petroleum Geologists: Alberta, Canada, 1989; Volume 13, pp. 271-276.

6. Copper, P. Reefs during the multiple crises towards the Ordovician-Silurian boundary: Anticosti Island, eastern Canada, and worldwide. Can. J. Earth Sci. 2001, 38, 153-171.

7. Nestor, H.; Copper, P.; Stock, C. Late Ordovician and Early Silurian Stromatoporoid Sponges from Anticosti Island, Eastern Canada: Crossing the O/S Mass Extinction Boundary; NRC Research Press: Ottawa, Canada, 2010; pp. 1-163.

8. Copper, P.; Brunton, F.R. A global review of Silurian reefs. Spec. Pap. Palaeont. 1991, 44, 225-259.

9. Brunton, F.R.; Copper, P.; Dixon, O.A. Silurian reef-building episodes. In Proceedings of the 8th International Coral Reef Symposium, Panama City, Panama, June 1996; Volume 2, pp. 1643-1650.

10. Copper, P. Silurian and Devonian reefs: 80 million years of global greenhouse between two ice ages. In Phanerozoic Reef Patterns; Kiessling, W., Flügel, E., Golonka, J., Eds.; SEPM: Tulsa, OK, USA, 2002; Volume 72, pp. 181-238.

11. Copper, P.; Fay, I. An Early Silurian reef complex, Manitoulin Island, northern Ontario. Mem. Can. Soc. Petrol. Geol. 1989, 13, 277-282.

12. Bergström, S.M.; Kleffner, M.; Schmitz, B.; Cramer, B.D. Revision of the position of the Ordovician-Silurian boundary in southern Ontario: Regional chronostratigraphic implications of $\delta^{13} \mathrm{C}$ chemostratigraphy of the Manitoulin Formation and associated strata. Can. J. Earth Sci. 2011, 48, 1447-1470.

13. Aaloe, A.O.; Nestor, H.E. Biogermnaya fatsiya v Yuruskom Gorizonte (nizhnii Llandoveri) v severo-zapadnoi Estonii [Biohermal facies in the Juuru Stage (lower Llandovery) in northwest Estonia]. In Facies and Fauna of the Baltic Silurian; Kaljo, D., Ed.; Akademiya Nauk Estonskoi SSR, Institut Geologii: Tallin, Estonia, 1977; pp. 71-88. 
14. Nestor, H. Silurian. Geology and Mineral Resources of Estonia; Raukas, A., Teedumäe, A., Eds.; Estonian Academy Publishers: Tallinn, Estonia, 1997; pp. 89-106.

15. Klaamann, E.R. Inkommunikatnye tabulyaty Estonii [The incommunicate Tabulata of Estonia]; Eesti NSV Teaduste Akadeemia Geoloogia Instituut: Tallinn, Estonia, 1966; p. 97.

16. Kaljo, D. Silur Estonii [Silurian of Estonia], Valgus: Tallinn, Estonia, 1970; p. 343.

17. Bolton, T.E. Geological map and notes on the Ordovician and Silurian litho- and biostratigraphy, Anticosti Island, Quebec. Geol. Surv. Can. 1972, 71(19), 1-45.

18. Bolton, T.E. Late Ordovician and early Silurian Anthozoa of Anticosti Island, Québec. In Proceedings of IUGS Subcommission on Silurian Stratigraphy, Ordovician-Silurian Boundary Working Group; Anticosti-Gaspé, Québec, Canada, February 1981; In Stratigraphy and Paleontology; Lespérance, P.J., Ed.; Université de Montréal: Montréal, Canada, 1981; pp. 107-135.

19. Kaljo, D. Fatsii I fauna Silura Pribaltiki [Facies and fauna of the Silurian of the Prebaltic]; Akademiya Nauk Estonskoi SSR, Institut Geologii: Tallinn, Estonia, 1977; p. 286.

20. Richardson, J. Report for the year 1856, of Mr. James Richardson, explorer, addressed to Sir William E. Logan, Provincial Geologist. In Report of Progress for the Years 1853-54-55-56; John Lovell: Toronto, Canada, 1857; pp. 191-245.

21. Schuchert, C.; Twenhofel, W.H. Ordovicic-Siluric section of the Mingan and Anticosti islands, Gulf of Saint Lawrence. Bull. Geol. Soc. Am. 1910, 21, 677-716.

22. Twenhofel, W.H. Faunal and sediment variation in the Anticosti sequence. Geol. Surv. Can. Bull. 1921, 33, 1-14.

23. Twenhofel, W.H. Geology of Anticosti Island. Geol. Surv. Can. Mem. 1928, 154, 1-481.

24. Petryk, A.A. Ile d'Anticosti, Geologic Map, Ministère de l'Energie et des Ressources, Québec, DPV 823 (three map sheets 1:100,000); Ministère de l'Energie et des Ressources: Québec, Canada, 1979.

25. Petryk, A.A. Stratigraphy, sedimentology and paleogeography of the Upper Ordovician-Lower Silurian of Anticosti Island, Québec. In Proceedings of IUGS Subcommission on Silurian Stratigraphy, Ordovician-Silurian Boundary Working Group; Anticosti-Gaspé, Québec, Canada, February 1981; In Stratigraphy and Paleontology; Lespérance, P.J., Ed.; Université de Montréal: Montréal, Canada, 1981; pp. 11-39.

26. Copper, P.; Long, D.G.F. Stratigraphic revision of the Jupiter Formation, Anticosti Island, Canada: A major reference section above the Ordovician-Silurian boundary. Newsl. Stratigr. 1990, 23, 11-36.

27. Copper, P. Articulate brachiopod shellbeds: Silurian examples from Anticosti, eastern Canada. Geobios Mém. Spéc. 1997, 20, 133-148.

28. Jin, J. Environmental control on temporal and spatial differentiation of Early Silurian pentameride brachiopod communities, Anticosti Island, eastern Canada. Can. J. Earth Sci. 2008, 45, 159-187.

29. McLean, R.A.; Copper, P. The early Silurian (late Rhuddanian-Telychian) rugose coral fauna of Anticosti Island, eastern Canada: Diversity during the post $\mathrm{O} / \mathrm{S}$ mass extinction recovery interval. Palaeontogr. Can. 2012, in press.

30. Long, D.G.F.; Copper, P. The Late Ordovician-Early Silurian Carbonate Tract of Anticosti Island, Gulf of St. Lawrence, Eastern Canada; Field Trip B4 Guidebook; Geological Association of Canada: Newfoundland, Canada, 1994; pp. 1-69. 
31. Copper, P.; Long, D.G.F. Sedimentology and paleontology of the Late Ordovician through Early Silurian shallow water carbonates and reefs of the Anticosti Island, Québec. In Sedimentology and Paleontology of the Late Ordovician through Early Silurian Shallow Water Carbonates of the Mingan Islands National Park and Anticosti Island, Québec; Field Trip B8 Guidebook; Desrochers, A., Copper, P., Long, D.G.F., Eds.; Geological Association of Canada-Mineralogical Association of Canada: Quebec, Canada, 1998; pp. 55-97.

32. Spalding, M.D.; Ravilious, C.; Green, E.P. World Atlas of Coral Reefs; University of California Press: Berkeley, CA, USA, 2001; p. 424.

33. Desrochers, A. Rocky shoreline deposits in the Lower Silurian (upper Llandovery) Chicotte Formation, Anticosti Island, Québec. Can. J. Earth Sci. 2006, 43, 205-1214.

34. Desrochers, A.; Bourque, P.A.; Neuweiler, F. Diagenetic versus biotic accretionary mechanisms of bryozoan-sponge buildups (Lower Silurian, Anticosti Island, Canada). J. Sediment. Res. 2007, 77, 564-571.

35. Billings, E. New species of fossils from different parts of the Lower, Middle and Upper Silurian rocks of Canada. Geol. Surv. Can. 1862, 1 (4), 96-168.

36. Lindström, G. Remarks on the Heliolitidae. Handl. Köngl. Svensk. Vetenskaps-akad. 1899, 32, 1-140.

37. Bourque, A.; Boulvain, F. A model for the origin and petrogenesis of the red stromatactis limestone of Paleozoic carbonate mounds. J. Sediment. Petrol. 1993, 63, 607-619.

38. Ausich, W.I.; Copper, P. The Crinoidea of Anticosti Island, Québec (Late Ordovician to Early Silurian). Paleontogr. Can. 2010, 29, 157.

39. Gauthier-Coulloudon, L.; Mamet, B.L. Algues et sedimentation carbonatés dans l'Ordovicien et la Silurien de l'île d'Anticosti. In Proceedings of IUGS Subcommission on Silurian Stratigraphy, Ordovician-Silurian Boundary Working Group; Anticosti-Gaspé, Québec, Canada, February 1981; In Stratigraphy and Paleontology; Lespérance, P.J., Ed.; Université de Montréal: Montréal, Canada, 1981; pp. 87-90.

40. Azmy, K.; Veizer, J.; Bassett, M.G.; Copper, P. Oxygen and carbon isotopic composition of Silurian brachiopods: Implications for coeval seawater and glaciations. Geol. Soc. Am. Bull. 1998, 110, 1499-1512.

41. Munnecke, A.; Samtleben, C.; Bickert, T. The Ireviken Event in the lower Silurian of Gotland, Sweden-Relation to similar Palaeozoic and Proterozoic events. Palaeogeogr. Palaeocl. Palaeoecol. 2003, 195, 99-124.

42. Cramer, B.D.; Loydell, D.K.; Samtleben, C.; Munnecke, A.; Kaljo, D.; Männik, P.; Martma, T.; Jeppsson, L.; Kleffner, M.A.; Barrick, J.E.; et al. Testing the limits of Paleozoic chronostratigraphic correlation via high-resolution $(<500 \mathrm{kyr})$ integrated conodont, graptolite, and carbon isotope $\left(\delta^{13} \mathrm{C}\right.$-carb) biochemostratigraphy across the Llandovery-Wenlock (Silurian) boundary: Is a unified Phanerozoic timescale achievable? Geol. Soc. Am. Bull. 2010, 122, 1700-1716.

\section{Appendix: Outcrops of East Point Member, Menier Formation}

UTM coordinates are prefixed with NTS map sheet numbers. Detailed locality data are available from the authors.

A196a-e (=A414), 12F/4, 97000:43470.

A197 (=A241), 12F/4, 96100:44250. 
A198, 12F/4, 94590:45440.

A199, 12F/4, 94320-94350:45920-46070.

A241 (=A197).

A318, 12F/4E, 95110:44650.

A319, 12F/4E, 93860:46970.

A322, 12F/4E, 96970-97060:42900-43150.

A414 (=A196).

A511, 12E/8, 52481:55897.

A702, 12F/4, 94520:45650.

A703, 12F/4, 97000:43000.

A735, 12E/1, 51769:54287.

A750, 12E/1, 37400:51100.

A835, 12E/6, 88500:80200.

A848 (=A750), 12E/1, 37400: 51100.

A849, 12E/1, 37600:50400.

A863 (=A1198) 12E/8, 52988:56255.

A917a-c (A1289), 12E/4, 4340:54000.

A918, 12E/1, 44210:53820.

A919, 12E/1, 43830:52850.

A926a-c, 12E/8, 54400:56000.

A930, 12E/8, 50130:56000.

A931, 12E/8, 50450:55800.

A934, 12E/8, 51960: 55790.

A935 (=A1149, A1202, A1496), 12E/8, 52481:55897.

A936, 12E/8, 53600:56400.

A950 (=A849).

A967a-b, 12E/11, 74760:89000.

A976, 12E/1, 71600:48900.

A980, 12E/6, 88509:80144.

A1059, 12E/1, 43830: 53000.

A1060, 12E/1, 43820:52900.

A1068, 12E/8, 49460:56850.

A1101a-b, 12E/11, 74800-74810:89000-89100.

A1149 (=A935, A1202, A1496).

A1157 (=A933).

A1167, 12E/1, 51810:54320.

A1196, 12E/1, 51880:54460.

A1198 (=A863).

A1199, 12E/8, 53084:56373.

A1199x, 12E/8, 53084:56373.

A1200, 12E/8, 52900:56000.

A1201 (=A934). 
A1202 (=A935, A1149, A1276, A1496).

A1203, 12E/8, 54710:56080.

A1204a-b, 12E/1, 42350:48280.

A1223, 12E/2, 34700:53560.

A1230, 12E/2, 24430:54350 (=A1230a); 24480:54370 (=A1230b).

A1241a-c, 12E/11, 74810: 89120.

A1272, 12E/8, 50150:56000.

A1273, 12E/8, 52000:55800.

A1274 (=A1198).

A1275 (=A863, A1199).

A1276, 12E/8, 52481:55897.

A1278, 12E/1, 51770:54460.

A1289 (=A917).

A1293 (=A1204).

A1384, 12F/4, 88100:49600.

A1385, 12F/4, 88160:49300.

A1386, 12F/4, 88160:49230.

A1387, 12F/4, 88720:47920.

A1388, 12F/4, 88800:47500.

A1489, 12E/8, 54995:55754.

A1492a-b, 12E/1, 56854:54164.

A1496a-b (=A1149, A935).

(C) 2012 by the authors; licensee MDPI, Basel, Switzerland. This article is an open access article distributed under the terms and conditions of the Creative Commons Attribution license (http://creativecommons.org/licenses/by/3.0/). 